
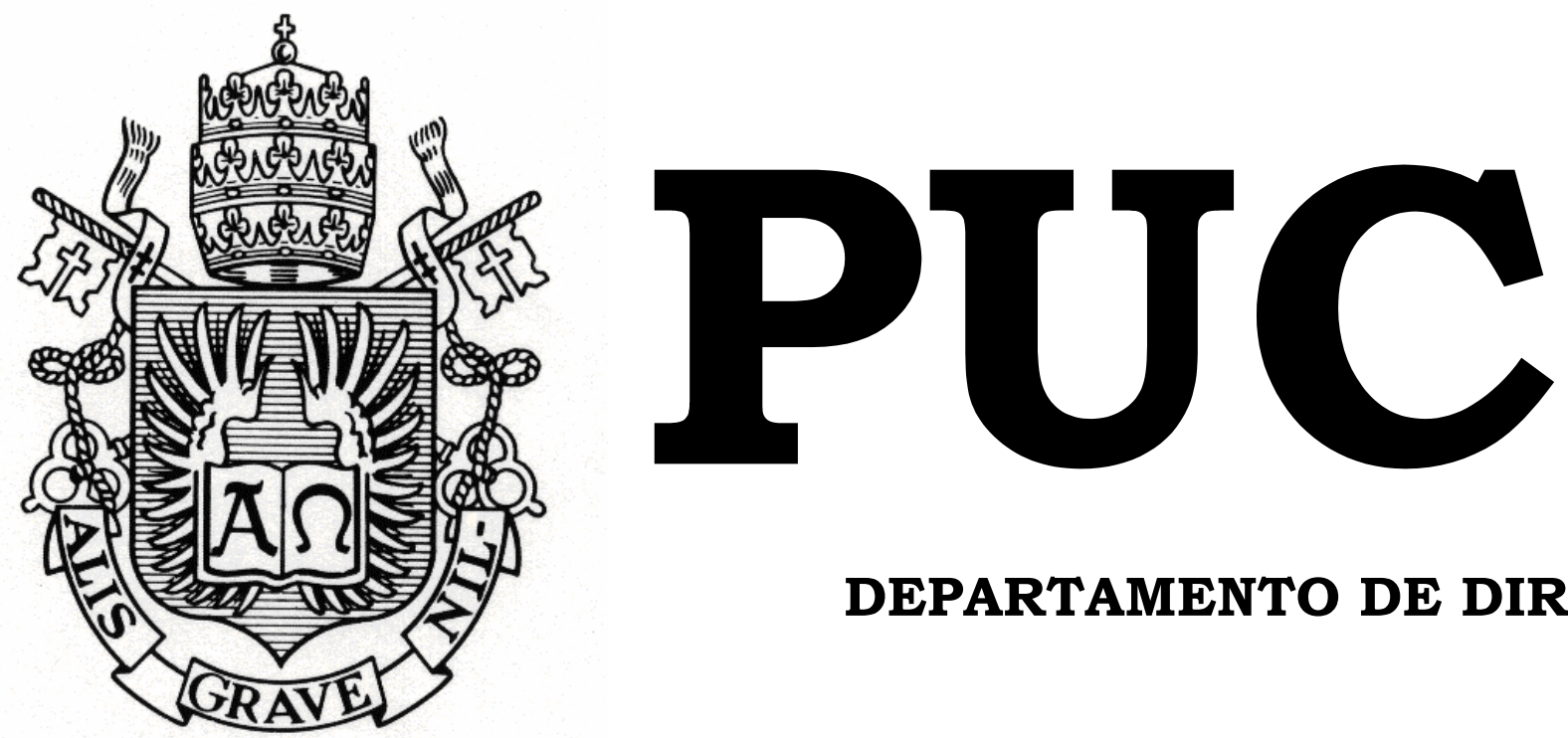

DEPARTAMENTO DE DIREITO

\title{
Principio da isonomia: o direito da mulher negra no mercado de trabalho \\ por
}

\section{ANGELA MARIA BATISTA \\ orientador:}

Lila Carolina Mota Pessoa Igrejas Lopes

2005.1

PONTIFÍCIA UNIVERSIDADE CATÓLICA DO RIO DE JANEIRO

RUA MARQUÊS DE SÃO VICENTE, 225 - CEP 22451-900

RIO DE JANEIRO - BRASIL 


\title{
Principio da isonomia: o direito da mulher negra no mercado de trabalho
}

\author{
por

\section{ANGELA MARIA BATISTA} \\ Monografia apresentada ao \\ Departamento de Direito da \\ Pontifícia Universidade Católica \\ do Rio de Janeiro (PUC-Rio) como \\ requisito parcial para a obtenção \\ do Título de Bacharel em Direito.
}

Orientador: Lilá Carolina 
Dedico esse trabalho a minha família e, em especial a minha querida mãe e amiga Baldoína (in memorian) que sempre me incentivou e acreditou nos meus sonhos, ao meu pai Messias exemplo de luta e sabedoria, amigos, professores do PVNC (Pré-Vestibular para Negros e Carentes) com os quais compartilho essa vitória e ao Frei Davi, incansável na luta em prol da igualdade, enfim todos que direta ou indiretamente colaborara para que esse sonho se transformasse em realidade. 


\section{Agradecimento}

A Deus, pai eterno, meu guia e minha luz nos momentos de incerteza presença constante em todos os momentos.

Aos irmãos da Comunidade Senhor do Bonfim pelo incentivo e interesse e torcida pela minha vitória.

Aos Professores da Pontifícia Universidade Católica por dividirem comigo o saber.

A Lila Carolina, orientadora do presente trabalho pela atenção, disponibilidade, firmeza e seriedade na orientação.

Ao professor Augusto Sampaio, Vice-Reitor Comunitário por tornar possível esta conquista.

Ao FESP (Fundo de Solidariedade da PUC-Rio) seus funcionários e colaboradores a minha eterna gratidão.

Ao meu fraterno amigo Rulian Emmerick a quem Deus me deu a chance de conhecer, minha gratidão eterna pela ajuda e incentivo nos momentos difíceis. 


\section{Resumo}

Fazendo uma análise profunda da situação em que se encontram as mulheres negras no Brasil por meio deste trabalho, chega-se a uma triste constatação de que são elas as maiores vítimas da discriminação racial que penaliza, marginaliza e exclui a população negra deste país do desenvolvimento e das riquezas que aqui são produzidas.

O dano moral provocado por quase quatro séculos de escravidão permaneça até hoje, 116 anos após a abolição da escravatura fazendo com que o negro continue sem identidade, cidadania e dignidade.

A luta dos movimentos negros é no sentido de chamar a atenção da sociedade para a condição desumana que está sendo submetido o povo negro deste país e das autoridades para que todos juntos busquem meios para se implantar políticas públicas que propiciem as mudanças almejadas, ações que promovam a igualdade e a inclusão do negro dentro da sociedade e medidas enérgicas que possam combater a prática da discriminação racial . 
"Eu desconfiava: (...) todas as guerras são iguais todos os amores, iguais, iguais, iguais. Iguais todos os rompimentos. A morte é igualíssima. Todas as criações da natureza são iguais. Todas as ações, cruéis, piedosas ou indiferentes são iguais.

Contudo, o homem não é igual a nenhum outro homem, bicho ou coisa. Ninguém é igual a ninguém todo ser humano é um estranho ímpar”

Poema: Igual-desigual.

(Carlos Drummond de Andrade) 


\section{Sumário}

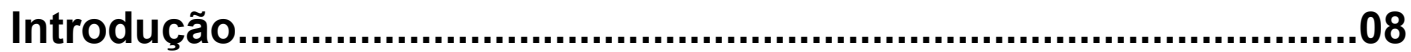

Capítulo I - Princípios Norteadores do Direito do Trabalho............11

1.1-Normas Protetivas na Constituiçãode1988.................... 23

1.2-Tratados Internacionais e Legislação Infraconstitucional

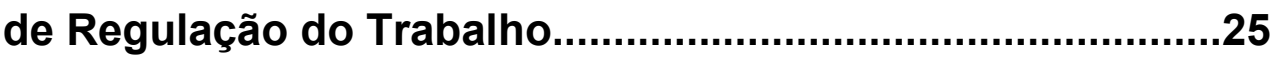

Capítulo II- O princípio da Isonomia.................................................30

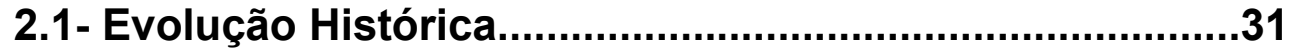

2.2- O Princípio da Igualdade nas Constituições Brasileiras. .33

2.3- Igualdade formal, material e a questão das desigualdades. 38

Capítulo III - O Ingresso da Mulher no Mercado de Trabalho.........42

3.1- A Situação da Mulher Negra brasileira no Trabalho.......45

3.2- A Questão Racial como fator preponderante na desigualdade de acesso da mulher negra ao mercado de trabalho. .47

Capítulo IV - Igualdade e Ação Afirmativa.......................................52

4.1- A Política das Cotas como meio de inclusão...................54

4.2- Polêmica Acerca da Política das Cotas..........................55

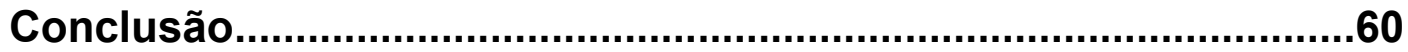

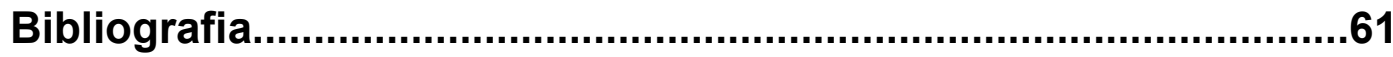




\section{Introdução}

O presente trabalho tem por objetivo tratar de um tema que não é novo, mas que continua atual, a discriminação em suas diversas formas principalmente a racial. As mulheres em todas as sociedades sempre sofreram com a discriminação em virtude da condição feminina, e dentro desse gênero existem aquelas que sofrem a discriminação em "dose dupla", tanto a de gênero como a de raça, dentro dessa situação se enquadram as mulheres negras.

A abordagem do tema será feita no âmbito do trabalho não significa que ela não exista em outras áreas, mas é no mercado de trabalho que se encontra a forma mais fácil de mostrar os efeitos que a discriminação provoca no seguimento social contra o qual ela é praticada.

No primeiro capítulo vamos mostrar como os estados por meio da criação de normas cuidam da proteção de seus trabalhadores. O Direito do Trabalho surge assim como principal regulador do mercado formal, por meio das normas positivadas na Constituição e leis infraconstitucionais ele entra na relação trabalhista tendo como objetivo regular os contratos celebrados entre empregados e empregadores para evitar que sejam cometidos abusos no momento em que os contratos são assinados e no correr destes que existe relação de desigualdade entre os sujeitos da relação.

O segundo capítulo mostra a evolução histórica do Princípio da Isonomia até os dias atuais. O Princípio da Igualdade assim como a humanidade, não é estático na medida em que a sociedade vai evoluindo ele também se transforma para se adequar aos avanços. O sonho de liberdade e igualdade acompanha o homem desde a antiguidade até os dias atuais como vemos no pensamento dos filósofos como Licurgo, Aristóteles até chegar em 
Rousseau e a Revolução Francesa. Porém mais que igualdade a sociedade desse tempo lutava para se libertar de um regime político opressor.

Nos dias atuais o direito a igualdade é perseguido pelo homem moderno como forma de sanar as profundas desigualdades provocadas por um novo modelo econômico implantado com o objetivo de trazer benefícios para os povos, porém os resultados tem sido justamente o contrário além de concentrar mais riquezas nos Estados que já eram ricos aumentou a pobreza nos países já considerados muitos pobres, aprofundando as desigualdades.

Diante desse quadro, o direito à igualdade se torna essencial a ser conquistado de forma plena pelo homem moderno.

No terceiro capítulo vamos mostrar, como se deu o ingresso da mulher no mercado de trabalho, a discriminação sofrida obrigou os países a tomarem medidas e editar normas de proteção em virtude do tratamento indigno dispensado às mulheres no mercado de trabalho. Tratados e convenções foram realizados e muitas resoluções saídas nos encontros entre países transformaram-se em normas protetivas de trabalho juntamente com as normas internas de cada Estado.

A situação da mulher negra no mercado de trabalho e a questão racial que aparece como um grande obstáculo que barra o seu acesso ao desenvolvimento à educação e aos cargos de destaque no mercado de trabalho. Pesquisas feitas por órgãos do Ministério do Trabalho mostram que são elas duas vezes vítimas da discriminação tanto a de gênero como de cor, por esse motivo são destinados a elas os cargos de menor prestígio social na escala do mercado de trabalho uma vez que o maior contingente de empregadas domésticas é de mulheres negras. 
O quarto capítulo mostra o que vem sendo feito no mundo para propiciar a inclusão das minorias marginalizadas das sociedades. As políticas públicas e o movimento denominado ação afirmativa é o cominho que países como Estados Unidos, Inglaterra, Canadá e outros, vêm trilhando no sentido de facilitar o acesso das minorias no mercado de trabalho, nas universidades, áreas de lazer ao destinar a estes cotas mínimas que lhes permitam competir com a maioria.

Porém, nos países onde foram implantadas, essas medidas estão sendo duramente criticadas, por ferir o consagrado princípio constitucional da isonomia para alguns, por serem discriminatórias com a maioria que estão perdendo seus espaços para a minoria. Em favor das cotas pesam o argumento de que nos países em que essa política é aplicada trouxe benefícios econômicos sensíveis nas classes com ela beneficiada.

No Brasil a política de ação afirmativa ainda é tímida, ficando restrita a algumas e poucas iniciativas de implementação de políticas de cotas, como a que está em funcionamento na UERJ (Universidade do Estado do Rio de Janeiro), embora incida sobre ela duras críticas. Também podemos ressaltar a cota destinada as deficientes nos concursos públicos que perfaz uma percentagem de $20 \%$ vagas existentes. 


\section{Capítulo I}

\section{Princípios Norteadores do Direito do Trabalho}

O Direito do Trabalho apresenta-se no mundo jurídico como um complexo de princípios e normas aparentemente dispersas cuja função fundamental é regular as relações de trabalho entre empregados e empregadores. É considerado um direito fundamental dos trabalhadores garantido por quase todos os Ordenamentos Jurídicos que tem como regime político a Democracia, é uma forma singular do Estado intervir nas relações particulares sem, no entanto, desrespeitar as ordens jurídico-econômicas e políticas já estabelecidas.

As normas de Direito do Trabalho regulam principalmente, as relações definidas como trabalho humano subordinado, como bem ensina Orlado Gomes. ${ }^{1}$

"O trabalho como expressão da personalidade humana, como atributo do "ser" e qualificado na sua forma de dependência. O sujeito da relação emprega não só as suas energias físicas, que não são por si mesmas um objeto descartável do ente humano, mas ainda investe a própria pessoa humana, como fonte permanente da qual emanam aquelas energias".

É essa relação de trabalho que será tratada nesse item, falaremos de alguns princípios importantes usados como fonte de orientação pelos doutrinadores, legisladores e aplicadores da lei. O primeiro a ser analisado é o Princípio da Proteção, também conhecido como Princípio Tutelar, este está ligado a própria razão de ser do Direito do Trabalho. Historicamente o Direito do Trabalho surgiu como conseqüência de que a liberdade de celebrar um contrato entre pessoas com poder e capacidade econômica desiguais conduzia a

\footnotetext{
${ }^{1}$ GOMES, Orlando. Curso de Direito do Trabalho. $12^{\mathrm{a}}$ ed. Rio de Janeiro: Editora Forense, 1991. p.11.
} 
várias formas de exploração abusivas contra a parte considerada mais fraca qual seja, o empregado.

O Direito do Trabalho fundamenta-se precipuamente no propósito de nivelar as desigualdades. Conture, segundo Plá Rodriguez, dizia que "o procedimento lógico de corrigir as desigualdades é o de criar outras desigualdades".2

Esse procedimento se torna claro nas três formas distintas que expressão o princípio tutelar dentro das regras trabalhistas:

a) a regra in dúbio, pro operário. Critério do qual o juiz e o aplicador da lei deve-se utilizar para escolher entre os vários sentidos possíveis de uma norma, aquela que seja mais favorável ao trabalhador;

b) a regra da norma mais favorável determina que, no caso de haver mais de uma norma aplicável, a opção deve recair sobre aquela mais favorável, ainda que não seja a que corresponda aos critérios clássicos de hierarquia das normas;

c) a regra da condição mais benéfica. Por esse critério nenhuma nova norma trabalhista deve servir para diminuir as condições mais favoráveis em que se encontrava um trabalhador.

São essas regras resultantes do mesmo princípio geral, mas que não devem ser consideradas subordinadas ou derivadas de outra.

Dentro dessas regras estão condicionadas as duas formas de aplicação do princípio, quais sejam:

\footnotetext{
${ }^{2}$ RODRIGUEZ, Américo Plá. Princípios de Direito do Trabalho. Trad. Wagner D. Giglio. São Paulo: LTr, 1978. p. 28-29.
} 
a) somente quando exista dúvida sobre o alcance da norma legal;

b) sempre que não esteja em desacordo com a vontade do legislador.

Amauri Mascaro, citado por Plá Rodrigues, afirma que, ${ }^{3}$

“A prevalência das disposições mais favoráveis ao
trabalhador se aplica, salvo lei proibitiva do Estado. A
prevalência da lei proibitiva do Estado resulta do fato
de que tal atitude se torna necessária quando o bem
comum exige sacrifícios momentâneos de vantagens
aparentes, em benefício de determinadas categorias
econômicas ou mesmo dos trabalhadores, em geral.
(...) Porém, como essas leis proibitivas constituem
normas excepcionais que se diferenciam das comuns
do Direito do Trabalho, devem estabelecer de alguma
maneira, de forma expressa, seu caráter de ordem
pública”.

Outro princípio importante é o da Irrenunciabilidade, que veda qualquer possibilidade do trabalhador voluntariamente renunciar direitos concedidos pela legislação trabalhista. A noção de irrenunciabilidade em termos gerais pode ser expressa como: a impossibilidade jurídica de privar-se voluntariamente de uma ou mais vantagens concedidas pelo direito trabalhista em benefício próprio. ${ }^{4}$

Enquanto no direito comum rege o Princípio da Renunciabilidade, no Direito do Trabalho acontece o oposto visto que ninguém pode privar-se das possibilidades ou vantagens estabelecidas em seu proveito próprio. Ao citar como exemplo o art. $4^{\circ}$ do Código Civil do seu país, o autor espanhol Hinojosa em sua obra "El Contrato de Trabajo. Comentários a la Ley de 1931", expõe de forma clara o antagonismo existente entre o princípio da renunciabilidade do Direito comum com o da irrenunciabilidade do Direito do Trabalho, "os

\footnotetext{
${ }^{33}$ Ibid. p. 55.

${ }^{4}$ De La Villa, citado por Plá Rodríguez, definiu a renuncia como um negócio jurídico unilateral que determina o abandono irrevogável de um direito, dentro dos limites estabelecidos pelo ordenamento jurídico.
} 
direitos concedidos pelas leis são renunciáveis, a não ser que esta renúncia seja contra o interesse ou a ordem pública ou em prejuízo de terceiros”, e acrescenta: ${ }^{5}$

"na renúncia por parte do operário dos benefícios que a lei lhe concede, se dão as duas circunstâncias que tornam impossível a renúncia. É questão de ordem pública que o trabalho humano seja devidamente protegido e remunerado; que a cobiça não explore a necessidade; que impere a verdadeira liberdade, não diminuída por entraves econômicos. E seria quase sempre em prejuízo de terceiro - dos familiares do trabalhador, dos companheiros de trabalho, que, por sua tibieza, se veriam constrangidos a aceitar condições inferiores de trabalho - a renúncia de seus direitos, que equivaleria, além disso, à das condições indispensáveis para a efetividade do direito à vida". 6

Para alguns autores, fundamento do principio da irrenunciabildade baseia-se em outro princípio importante, o da indisponibilidade; já para outros, esse fundamento deve ser buscado dentro da noção de ordem pública; outros autores afirmam que ele é uma forma de limitação da limitação da autonomia da vontade, porém, para a grande maioria deles, o fundamento do princípio está relacionado com o caráter imperativo das normas trabalhistas, dentre estes, Mario de La Cuerva, este autor afirma que: ${ }^{7}$

"O Direito do Trabalho, como direito imperativo é garantia constitucional, ao regular as relações entre o Capital e o trabalho, se dirige, por um lado, a cada patrão e a cada trabalhador, por ocasião do estabelecimento das relações e, por outra, ao Estado, enquanto o obriga a zelar para que as relações se constituam na forma dos princípios contidos na lei e nas normas que a suprem, e sejam por elas governadas".

A noção de ordem pública significa que o Estado considerou melhor excluir a possibilidade de que as partes acordem por decisão própria a

\footnotetext{
${ }^{5}$ Ibid. p. 66.

${ }^{6}$ Ibid. p. 66.

${ }^{7}$ Ibid. p. 70 .
} 
regulamentação de sua conduta, de maneira diversa da que tenha estabelecido o legislador. Para que a definição da noção de ordem pública se torne mais clara ao entendimento é importante mencionar alguns autores citados por Américo Plá Rodriguez. ${ }^{8}$ Onde entre eles figuram os seguintes:

Clóvis Bevilaqua:

"Leis de ordem públicas são aquelas que, em um estado, estabelecem os princípios, cuja manutenção se considera indispensável à organização da vida social, segundo os preceitos do direito".

Evaristo de Moraes Filho:

"Ordem Pública significa que não pode ser derrogado, renunciado, por simples manifestação de vontade dos particulares. É o que o Estado julga imprescindível e essencial para a sobrevivência da própria sociedade, o bem comum, o interesse geral. Sempre, em todos os tempos, uma certa porção de atos humanos foram tidos como necessários e obrigatórios para esse desideratum."

Juan Carlos Smith:

"Conjunto de condições fundamentais da vida social, instituídas em uma comunidade jurídica, as quais, por afetarem no âmago a organização desta, não podem ser alteradas pela vontade dos indivíduos nem, se for o caso, pela aplicação de normas estrangeiras".

Quanto à noção fundada na limitação da autonomia da vontade no Direito de Trabalho, esta se aplica na medida em que a vontade das partes não pode, pelo contrato de trabalho, convenção coletiva ou contrato de seguro privado, ferir os bons costumes, as bases da ordem pública do Estado ou as normas proibitivas expressas, que tendem a proteger situações de direito especiais. O objetivo do legislador ao transplantar a autonomia da vontade do terreno individual para o terreno coletivo foi evitar abusos no momento de

\footnotetext{
${ }^{8}$ Ibid. p. 73 .
} 
celebrar contratos entre indivíduos de poder e de situação econômica desigual. Alonso Garcia, citado por Plá Rodriguez, expressa: ${ }^{9}$

“As limitações à autonomia privada têm, pois, no
plano jurídico-trabalhista, um significado evidente:
representam o restabelecimento necessário dos
pressupostos iniciais sobre os quais se deve aventar a
possibilidade dogmática do contrato, isto é, o princípio
da igualdade das partes. Porque é então, e unicamente
então, que se pode exigir o respeito mútuo de uma
parte as condições por ela mesma aceitas".

"A autonomia privada encontra o fundamento de suas limitações na mesma composição da ordem social, na natureza da sociedade e dos valores, onde impera uma necessária submissão da vontade autônoma aos ditames dos interesses superiores, constitutivos da comunidade existência, indispensáveis para poder ordenar devidamente a realidade social através de meios jurídicos (...)".

No tocante ao caráter imperativo das normas trabalhistas, idéia apontada pela maioria, como sendo este o principal fundamento do Princípio da Irrenunciabilidade é importante esclarecer que esta não guarda semelhança com aquela da imperatividade das normas jurídicas, uma vez que todas as normas são imperativas, pois contém um mandamento, uma ordem, mas relaciona sim com a distinção entre normas imperativas e normas distintivas, divisão aplicada no Direito Romano com relação ao jus cogens e jus dispositivum. O primeiro é integrado por normas que devem ser cumpridas qualquer que seja a vontade das partes. O segundo, é constituído de normas que se devem cumprir só quando as partes não tenham estabelecido outra coisa.

Para melhor ilustração da idéia de imperatividade das normas trabalhistas, Américo Plá Rodriguez cita vários autores dentre estes, Mario de la Cueva e Francisco de Ferrari.

\footnotetext{
${ }^{9}$ Ibid. p. 76.
} 
Mario de la Cueva, em sua obra "Derecho Mexicano Del Trabajo" de 1943 afirma: ${ }^{10}$

"O Direito do Trabalho, como direito imperativo e garantia constitucional, ao regular as relações entre o capital e o trabalho, se dirige, por um lado, a cada patrão e a cada trabalhador, por ocasião do estabelecimento das relações, e por outra, ao Estado, enquanto o obriga a zelar para que as relações se constituam na forma dos princípios contidos na lei e nas normas que a suprem, e sejam por elas governados".

Francisco de Ferrari, "Derecho del Trabajo" Buenos Aires, 1968, tem posição similar ao afirmar que,

"As regras de Direito do Trabalho tem, em geral, caráter imperativo e irrenunciável. O Estado dá as certas normas caráter imperativo e concede um poder de vigência inderrogável pelas partes, em virtude de diferentes razões. No caso das leis do trabalho, a imperatividade se baseia no interesse e na necessidade de proteger os economicamente débeis".

Portanto, cabe ao Estado o dever de zelar pela observância e exigir daqueles que de alguma forma estejam envolvidos na relação, o cumprimento das normas de Direito do Trabalho. ${ }^{11}$

Outro princípio importante é o da Continuidade cuja base está relacionado e ao trato sucessivo do contrato de trabalho, ou seja, a relação de emprego não se esgota mediante a realização instantânea de um certo ato. É uma vinculação que se prolonga no tempo. O Princípio da Continuidade permite que o empregado execute suas tarefas com tranqüilidade e segurança

\footnotetext{
${ }^{10}$ Ibid. p. $70-71$.

${ }^{11}$ La Cueva citado por Plá Rodriguez observa que: "Sem este caráter imperativo manifesto nessa dupla direção da norma, não seria o Direito do Trabalho um mínimo de garantias, nem preencheria sua função; pois se a idéia de garantias, seja individual ou social, faz-se referência à aquelas normas cuja observância se considera essencial para a realização da justiça, deixa-las subordinadas à vontade de trabalhadores e patrões equivale a destruir seu conceito, como princípio de cuja observância é o Estado encarregado".
} 
uma vez que este lhe garante a conservação da fonte de trabalho, a sensação de tranqüilidade, garante o aumento na produção, beneficia a empresa e sociedade na medida em que o aumento no lucro revestido em prol da sociedade trazendo melhorias no clima social.

O verdadeiro alcance deste princípio assenta-se em várias projeções:

a) Preferência pelos contratos de duração indefinida;

b) Amplitude para admissão das transformações do contrato;

c) Facilidade para manter o contrato, apesar dos descumprimentos ou nulidades em que se haja incorrido;

d) Resistência em admitira a rescisão unilateral do contrato, por vontade patronal;

e) Interpretação das interrupções dos contratos como simples suspensões;

f) Manutenção do contrato nos casos de substituição do empregador.

Esse conjunto de projeções não se trata de regras absolutas, rígidas, denotam apenas tendências e orientações predominante que, no entanto, admitem exceções, limitações e restrições, mas, permitem que a continuidade se sobreponha à fraude, à variação, à infração, à arbitrariedade, à interrupção e à substituição.

Podemos destacar também dentro do Direito do Trabalho o Princípio da Primazia da Realidade. Este significa que, em caso de discordância entre o que ocorre na prática e o que emerge de documentos ou acordos, deve-se dar preferência ao primeiro, isto é, ao que sucede no terreno dos fatos. 
O fundamento deste princípio baseia-se em diferentes motivações, passando pela exigência da boa fé, dignidade da atividade humana, desigualdade das partes e a interpretação racional da vontade das partes.

A primeira resulta do princípio da boa fé. Diz da necessidade da realidade mostrar sempre a verdade. O documento pode mostrar a verdade porém, fictícia dissimulada pelo objetivo de impedir o cumprimento de obrigações legais ou de obter um proveito ilícito, ainda que as discordâncias entre os fatos e o documento não provenha da má fé, a afirmação da primazia dos fatos serva para cobrir tantos os erros intencionais como os involuntários.

O segundo deriva do conteúdo do contrato, que pressupõe uma continuidade, ou seja, a atividade humana prolongada no tempo. Deve-se levar em conta que o Direito do Trabalho regula a atividade humana e se essa atividade derivar de um contrato de trato sucessivo, o caráter desse contrato vai determinar uma dinâmica levando-o a possíveis e freqüentes modificações que devem estar assentadas na documentação do trabalhador e em conformidade com as normas trabalhistas aplicadas. A preocupação maior não é com o documento formal, mas sim, a atividade humana, e qualquer divergência existente entre atividade e documento o que vai interessar é a realidade do trabalho e não a formalidade.

A terceira provém da desigualdade das partes. È do conhecimento de todos que existe uma desigualdade cultural e econômica que separa as partes no contrato. Esse foi um dos pressupostos que deu origem ao Direito do Trabalho que busca compensar com a desigualdade jurídica a desigualdade econômica, através da criação de vários mecanismos como: elaboração de leis protetivas, intervenção nos sindicatos para que nas negociações coletivas, haja uma compensação de forças dos trabalhadores tornando as discussões entre empregados e empregadores de forma mais igualitária. 
Apesar de todos esses mecanismos ainda não foi possível esse equilíbrio de forças, a igualdade entre as partes no contrato de trabalho continua um sonho de conquista muito distante. ${ }^{12}$

A quarta motivação para a fundamentação do Princípio da Primazia da Realidade está vinculada à interpretação racional da vontade das partes. Nesse sentido, Jorge Gamarra em "Tratado de Dercho Civil Uruguaio" afirma que "não importa para estabelecer a vontade tácita se requeira um procedimento de dedução, porque uma vez que esta se realize, a vontade se reputa estabelecida". ${ }^{3}$ Significa dizer que a vontade contratual tanto pode se manifestar de forma expressa como tácita, tanto uma forma, como outra é válida desde que não exista uma norma legal excluindo a manifestação tácita, dentro de um certo âmbito.

Princípio da Razoabilidade. Este princípio diz que o homem deve agir com razoabilidade e toda forma de arbitrariedade deve ser proibida para que o ideal de justiça se concretize. Trazer essa afirmativa para o campo do Direito do Trabalho significa dizer essencialmente que o ser humano nas suas relações trabalhista deve proceder conforma à razão.

Sua aplicação ultrapassou os limites do Direito do Trabalho atingindo a seara constitucional, um bom exemplo disso está em um entendimento jurisprudencial da Suprema Corte dos Estados unidos.A justiça norteamericana tem aplicado o critério da razoabilidade para a determinação de quais são as limitações ao princípio de igualdade estabelecida pela Constituição, de que pode dispor o legislador. O reconhecimento da igualdade entre todos os seres humanos não significa a impossibilidade de estabelecer leis aplicáveis a certo grupo de pessoas. Essa é uma influência do critério da

\footnotetext{
${ }^{12}$ Ibid. p. 228

${ }^{13}$ Ibid. p. 229
} 
razoabilidade para justificar uma discriminação dentro do princípio da igualdade é um limite, mas, não significa de forma alguma gravame à igualdade constitucional. ${ }^{14}$

A jurisprudência norte-americana foi desenvolvendo passo a passo o princípio da razoabilidade, a partir do due process of law. Inicialmente teve um alcance puramente processual ou instrumental para adquirir em seguida um sentido substantivo, convertendo-se em uma espécie de garantia constitucional inominada. Deve existir, no entanto, uma substancial razoabilidade entre a lei a ser aplicada e a segurança garantida. Para garantir esse equilíbrio faz-se necessário o uso de alguns critérios determinantes, quais sejam:

a) comparar o equilíbrio das vantagens que um ato do Estado traz à comunidade, com os encargos que lhe custa;

b) adequação entre o meio empregado pelo ato e a finalidade que ele colima; e

c) conformidade do ato com uma série de princípios, aos quais se considera ligada a existência da sociedade. ${ }^{15}$

No Direito do Trabalho vamos nos ater a duas grandes formas de aplicação deste princípio: o critério da verossimilhança e da racionalidade.

A verossimilhança serve para medir determinada explicação ou solução de alguns casos ou situações em que o trabalho de uma pessoa é colocado a serviço de outra, mediante o pagamento ou retribuição de forma confusa que em muitos casos dependem de uma análise detalhada para se determinar se ali existe ou não uma relação trabalhista. Não raro isso acontece nas práticas comerciais e industriais em virtude do dinamismo dessas atividades.

\footnotetext{
${ }^{14}$ Ibid. p. 246

${ }^{15}$ Ibid. p. 247
} 
O critério da racionalidade serve como meio para distinguir situações limites entre realidade e simulação, quando não há outros elementos de juízo para resolução do caso. Baseia-se no pressuposto que o homem comum atua normalmente de acordo com a razão enquadrado em certos padrões de conduta que devem ser seguidos por serem os mais lógicos.

$\mathrm{Na}$ relação trabalhista, uma pessoa é colocada sob a subordinação de outra, durante um certo tempo, executando tarefas obedecendo às ordens sobre a melhor forma de como executá-las. O poder de direção deve-se ater dentro dos limites adequados, mesmo tendo esta pessoa certa liberdade e discricionariedade de atuação em virtude do cargo de comando, a lei não the permite agir com arbitrariedade e despotismo. São estes dois principais critérios que permitem o Princípio da Razoabilidade atuar na legislação trabalhista de forma concreta.

O último a ser analisado é o Principio da Boa Fé cuja noção, consiste na afirmação de que ambas as partes devem realizar o máximo esforço para aumentar, incrementar a produção nacional na parte que dependa da empresa. Isso significa que este princípio age de forma complementar aos anteriormente estudados que em conjunto visam efetivar a proteção ao trabalhador, compensando-os com uma desigualdade jurídica favorável em virtude da desigualdade econômica existente em prejuízo do trabalhador.

Uma particularidade deste princípio é sua atuação fora do âmbito do Direito do Trabalho. A transcendência se dá quando vincula o trabalho com o aumento da produção, "incorporando a posição e o esforço de cada trabalhador e de cada empresário a um empreendimento nacional de alcance muito maior, 
como é o relativo ao aumento da produção global", na afirmação de Plá Rodriguez. $^{16}$

Porém, é importante afirmar que dentro do Direito do Trabalho, o Princípio da Boa Fé tem um sentido especial em virtude do componente pessoal que existe nesse ramo jurídico. O contrato de trabalho não cria apenas obrigações de ordem patrimonial, mas também pessoal, cria uma relação estável e continuada na qual se exige confiança recíproca. Para que esta relação se mantenha adequada é preciso que ambas as partes atuem de boa fé. Como assinala Ernesto Eduardo Borba, ${ }^{17}$

\footnotetext{
"a boa fé não é uma norma, nem se reduz a uma obrigação, mas é um princípio jurídico fundamental, isto é, algo que devemos admitir como premissa de todo ordenamento jurídico. Informa sua totalidade e aflora de maneira expressa em múltiplas e diferentes normas, ainda que nem sempre se mencione de forma explícita”.
}

Diante dessa afirmativa podemos dizer que a repercussão do princípio da boa fé transcende a meras obrigações, é antes de tudo uma exigência de conduta geral, um dever agir de todos os envolvidos em uma relação contratual seja qual for a forma e a finalidade do contrato.

\section{1- Normas Protetivas na Constituição da República de 1988}

O Direito ao trabalho é direito fundamental do trabalhador garantido por leis esparsas e normas constitucionais. Nos países de regime democrático do ponto de vista jurídico-constitucional em termos de importância e necessidade ele se compara ao direito à moradia. Ambos se comparam quando conjugados juntamente com o direito a sobrevivência se for medidos em uma escala de valor, a importância de ambos é a mesma.

\footnotetext{
${ }^{16}$ Ibid. P. 259

${ }^{17}$ Ibid. p. 262
} 
$\mathrm{Na}$ Constituição brasileira a primeira proteção ao trabalho encontra assento no artigo $1^{\mathrm{o}}, \mathrm{IV},{ }^{18}$

Art. $1^{\circ}$ A República Federativa do Brasil, formada pela união indissolúvel dos Estados e Municípios e do Distrito Federal, constitui-se em Estado Democrático de Direito e tem como fundamentos:

IV - Os valores sociais do trabalho e da livre iniciativa

$\mathrm{Na}$ parte dedicada as garantias fundamentais encontram-se mais uma proteção ao trabalho e o direito à liberdade quanto ao exercício da profissão no art. $5^{\circ}$, XIII:

Art. $5^{\circ}$, XIII - é livre o exercício de qualquer trabalho, ofício ou profissão, atendidas as qualificações profissionais que a lei estabelecer.

Significa que qualquer limitação à liberdade no exercício da profissão somente será possível em virtude de lei.

Além de fundamental, o Direito ao Trabalho também é considerado como direito social como está assentado no art. $6^{\circ}$ da Constituição do Brasil,

Art. $6^{0}$ - "São direitos sociais a educação, a saúde, o trabalho, a moradia, o lazer, a segurança, a previdência social, a proteção à maternidade e à infância, a assistência aos desamparados, na forma desta Constituição”. (grifo nosso).

A preocupação do constituinte em garantir a dignidade dos trabalhadores brasileiros está estampada mais uma vez no título que trata da ordem econômica. O artigo inaugural desse título espelha bem essa preocupação quando no art. 170 ensina que "à ordem econômica, fundada na valorização do

\footnotetext{
${ }^{18}$ Constituição da República Federativa do Brasil, promulgada em 05 de outubro de 1988.
} 
trabalho humano e na livre iniciativa, tem por fim assegurar a todos uma existência digna, conforme os ditames da justiça social, observados os seguintes princípios":

\section{$(\ldots)$}

VIII - Busca do pleno emprego.

Dentre as normas constitucionais que regulam o Direito do Trabalho merece destaque especial o art. $7^{\circ}$ e seus incisos. Esse artigo mostra a preocupação do constituinte em garantir e proteger pela via constitucional o direito ao trabalho a todo cidadão brasileiro. Entretanto, a efetividade plena dessas normas depende de ações conjuntas do poder público e da sociedade, a eficácia e a imperatividade das normas inseridas no artigo $7^{\circ}$ impõe ao Estado a obrigação de zelar para que todos os envolvidos na relação trabalhista respeitem as determinações que nelas estão contidas.

No Ordenamento Jurídico Brasileiro, além da Constituição, o Direito do Trabalho está regulamentado pela legislação ordinária, Convenções e Tratados Internacionais dos quais o Brasil é signatário. No próximo item falaremos de algumas leis importantes em vigor em nosso país.

\section{2 - Tratados Internacionais e Legislação Infraconstitucional de Regulação do Trabalho.}

No Brasil, a principal lei ordinária que trata da matéria trabalhista é a Consolidação das Leis do Trabalho. Instituída pelo Decreto-lei $n^{0} 5.452$ de 01/05/1945, que contém normas de Direito material e processual além de tratar, ainda, da organização e composição da Justiça do Trabalho, do Ministério Público e do processo do trabalho. Antes da CLT, as leis de proteção ao trabalhador, se restringiam as Constituições anteriores a de 1988, 
leis federais e estaduais como a Lei $\mathrm{n}^{0} 1.596$ de 29/12/17, que organizou o serviço sanitário de São Paulo. Essa lei proibia o trabalho de mulheres nos estabelecimentos industriais no último mês de gravidez e do primeiro mês após o parto, ou a na lei federal, Decreto $\mathrm{n}^{\mathrm{o}} 16.300$ de 21/12/1923, cuidava do Regulamento do Departamento Nacional de Saúde Pública, esse decreto facultava às mulheres que trabalhavam em estabelecimentos comerciais e industriais, um repouso de trinta dias antes e trinta dias após o parto. ${ }^{19}$

Com os avanços científicos e tecnológicos o mercado de trabalho também se modernizou e se transformou, atingindo diretamente as relações de trabalho. Com as modificações ocorridas, a legislação trabalhista precisou passar por reformas para se adaptar as transformações do mercado, com isso os legisladores foram criando novas leis para assegurar os direitos dos trabalhadores não alcançados pela CLT. Assim, em 08/06/1973 entrou em vigor a Lei 5.889 regulando o trabalho rural.

Art. $1^{\mathrm{o}}$ "as relações de trabalho rural serão reguladas por esta Lei e, no que com ela não colidirem, pelas normas da Consolidação das Leis do Trabalho".

Outra Lei de $\mathrm{n}^{\mathrm{o}} 7.195$ de 12 de junho de 1984 dispõe sobre a responsabilidade civil das agências de empregados doméstico.

Lei $\mathrm{n}^{\circ} 8.630$ de 25 de fevereiro de 1993 dispõe sobre o regime jurídico da exploração dos portos organizados e das instalações portuárias e dá outras providências. $^{20}$

Também a Lei $\mathrm{n}^{\mathrm{o}} 10.406$ de 10 de janeiro 2002 do Novo Código Civil é considerada lei infraconstitucional na medida em que o Título VI ao abordar as

\footnotetext{
${ }^{19}$ BARROS, Alice Monteiro de. A mulher e o Direito do Trabalho. São Paulo: LTr, 1995. p.413.

${ }^{20}$ Revista do Direito do Trabalho. São Paulo: ed. RT, 1996. p. 174/175.
} 
espécies de contrato, no capítulo VII dedica a regular a prestação de serviço, assevera em seu artigo 593 que $^{21}$ “a presta de serviço, que não estiver sujeita às leis trabalhistas ou especiais, reger-se-á pelas disposições deste Capítulo”.

Com relação às convenções e tratados desde quando o Brasil aceitou fazer parte como membro da Organização das Nações Unidas (ONU) passou a aderir aos acordos feitos pelos órgãos ligados à Organização.

A OIT (Organização Internacional do Trabalho) é um dos órgãos ligados à ONU criado com o objetivo de proteger os trabalhadores. Os princípios fundamentais de direitos no trabalho estão presentes em todas as ações da OIT. A razão da criação desse órgão em 1919 foi promover e harmonizar direitos do trabalho através do estabelecimento e aplicação de normas internacionais de trabalho.

No Brasil a receptividade das normas internacionais estabelecidas em convenções e tratados depende de ratificação e adequação ao ordenamento jurídico interno, as regras internacionais não podem estar em desacordo com as normas constitucionais. No âmbito internacional o país ratificou várias Convenções como a de $n^{0} 3$ de 13/06/1919 assegura a mulher empregada, independentemente do seu estado civil, uma licença remunerada compulsória de seis semanas antes e seis semanas após o parto, além de dois intervalos de trinta minutos cada um para aleitamento. Essa Convenção foi revista em 1952 pela de n. ${ }^{\circ} 103$. A Convenção de $n^{\circ} 100$ adota as disposições concernentes ao princípio da igualdade de remuneração, na prática, há dificuldades na aplicação da equivalência salarial entre homens e mulheres, não só no que tange o salário-base, mas também no salário indireto. ${ }^{22}$

\footnotetext{
${ }^{21}$ CAHALI, Yussef Said. Código de Direito Civil. São Paulo: Ed. RT. 2002. p. 96.

22 Ibid. p. 40/42/148.
} 
Em 1975 a OIT participou intensamente do Ano Internacional da Mulher, proclamado pela ONU. Esse programa permitiu o exame da situação da mulher, em nível mundial, nacional e regional, por parte de governos, organizações internacionais ou governamentais e outras instituições, pelos meios de informação de massa e por indivíduos de ambos os sexos. Nesse mesmo ano a OIT realizou a $60^{\mathrm{a}}$ Reunião da Conferência Internacional do Trabalho adotando uma Declaração sobre igualdade de oportunidades e de tratamento para as trabalhadoras. E mais duas Resoluções, uma traçando plano de ação com o objetivo de promover a igualdade de oportunidades e de tratamento para as trabalhadoras e a outra sobre a igualdade de condições e oportunidades para o homem e a mulher na profissão e no emprego. ${ }^{23}$

Em 1998 foi adotada a Declaração da OIT sobre os Princípios e Direitos Fundamentais do Trabalho e seu Seguimento. É um documento de reafirmação universal de compromisso dos Estados Membros, e da comunidade internacional de respeitar, promover e aplicar de boa-fé os princípios e direitos no trabalho referentes:

À liberdade de associação e de organização sindical e ao reconhecimento efetivo do direito de negociação coletiva;

À eliminação de todas as formas de trabalhos forçados ou obrigatórios;

À abolição efetiva de trabalho infantil;

À eliminação da discriminação em matéria de emprego e ocupação.

São, portanto, normas e regras que não eliminam as desigualdades nas relações de trabalho, mas é o único meio possível de equilibrar as forças

${ }^{23}$ Ibid. p. 164 
quando se fala em defesa de direitos antagônicos entre partes na relação contratual. 


\section{Capítulo II}

\section{O Princípio da Isonomia}

O Princípio da Igualdade não é estático, assim como o homem, ele está sempre em mutação, vai sendo elaborado e construído através da história, numa mudança constante e inacabada.

$\mathrm{O}$ anseio por um estado de bem estar e harmonia social fez com que o homem buscasse uma forma de convivência como a existente no passado, onde no estado de natureza, a igualdade era norma a ser observada e respeitada por cada indivíduo, por ser ela considerada um bem comum de todos, patrimônio único daquela sociedade. É essa idéia de igualdade que o homem procura resgatar no presente adaptando-a a nova forma de organização política social. A respeito da construção desse princípio, Cármen Lúcia Antunes Rocha afirma que, ${ }^{24}$

\footnotetext{
"O princípio jurídico da igualdade é o que a sociedade quer que ele seja. Não é obra de Deuses, nem de formas heterônomas, nem de forças exógenas que se impõem a uma sociedade com explicações mistificadas (..). A igualdade no Direito é arte do homem. Por isto o princípio jurídico da igualdade é tanto mais legítimo quanto mais próximo estiver o seu conteúdo da idéia de Justiça em que a sociedade acredita na pauta da história e do tempo".
}

Para se ter uma melhor compreensão da dinâmica a ser enfocada sobre o princípio da igualdade dentro do presente trabalho é necessário que se faça um breve histórico do surgimento, construção elaboração deste princípio desde os idos tempos até os dias atuais, como a idéia de igualdade foi sendo sedimentada dentro da sociedade.

\footnotetext{
${ }^{24}$ ROCHA, Cármen Lúcia Antunes, O princípio Constitucional da Igualdade. Minas Gerais: Editora Lê S/A .1990. 28 p.
} 


\section{1- Breve evolução histórica}

A idéia de igualdade remonta ao passado, coube a Licurgo a primazia de uma proposta efetiva no sentido de se fazer da igualdade um princípio jurídico, uma formulação social e até mesmo um projeto econômico a prevalecer em Esparta. Todavia esta primeira tentativa de realizar uma igualdade legal efetiva na sociedade romana redundou no amortecimento do ideal de liberdade como bem juridicamente protegido. ${ }^{25}$

Outro documento importante para o reconhecimento e concessão de uma esfera jurídica igualitária entre os romanos foi à edição da Lei das XII Tábuas, esse documento igualava patrícios e plebeus. Igualmente importante, o Edito Perpétuo, que estendia a igualdade às populações de outras etnias. Seguindo-se a este, o Edito de Caracalha ou Constitutio Antoniniano, que concedia o direito de cidadania a todos os habitantes do Império.

Entretanto coube a Rousseau, versar o tema da igualdade de forma a influenciar, decisiva e indisputavelmente, a estruturação do modelo de Estado surgido a partir das Revoluções levadas a efeito no final do Século XVIII. O pensamento de Rousseau, aliado às idéias de Montesquieu, influiria, decisivamente, na conduta dos revolucionários das colônias inglesas e na França.

A Constituição de Virgínia de 12 de junho de 1776 no seu art. $1^{\circ}$ preceitua que: "todos os homens são, por natureza, igualmente livres e independentes". Seguindo-se a esta, a Constituição da Pensilvânia de 12 de novembro de 1776 , e outras que passaram a acolher em seus respectivos textos o mesmo preceito. ${ }^{26}$

\footnotetext{
${ }^{25}$ Ibid. 29 p.

${ }^{26}$ Ibid. 32 p.
} 
Entretanto, foi o direito público francês que formalizou em primeiro lugar, a nível constitucional, a idéia jurídica da igualdade, estampando-a logo no art. $1^{\circ}$ da famosa Declaração dos Direitos do Homem e do Cidadão, de 1789, que preceitua: “Os homens nascem e permanecem livres e iguais em direitos. As distinções sociais não podem ser fundamentadas senão sobre a utilidade comum". E de forma mais concreta no art.VI da mesma declaração que diz: "A lei é a expressão da vontade geral. Todos os cidadãos têm o direito de concorrer, pessoalmente ou pelos seus representantes, na sua formação. Ela tem de ser a mesma para todos, quer seja protegendo, quer seja punindo. Todos os cidadãos, sendo iguais aos seus olhos, são igualmente admissíveis a todas as dignidades, lugares e empregos públicos, segundo a capacidade deles, e sem outra distinção do que a de suas virtudes e talentos". A Declaração dos Direitos do Homem e do Cidadão, posteriormente, foi incorporada como forma de preâmbulo ao texto constituinte adotado a 03 (três) de setembro de 1791 .

O ideal da igualdade desde então nasce nas Constituições Modernas, no plano jurídico-positivo como poderoso instrumento de reação contra os privilégios pessoais e a hierarquização das classes sociais que, com variantes puramente culturais, vigorou por toda antiguidade, na Idade Média e no renascimento absolutista. O Princípio da Isonomia, após a $2^{\text {a }}$ metade do Século XIX, nasce como fonte inesgotável de argumentos para o ideário igualitarista, que incendeia a história do pensamento político-econômico, espalhando suas centelhas até os dias atuais.

Paradoxalmente, porém, nas sábias palavras do Ilustre Jurista, Carlos Roberto de Siqueira Castro, ${ }^{27}$

\footnotetext{
${ }^{27}$ CASTRO, Carlos Roberto de Siqueira, O Princípio da Isonomia e a Igualdade da Mulher no Direito Constitucional. Rio de Janeiro: Editora Forense, 1983. 35/36 p.
} 
"O avanço dos movimentos em prol da diminuição das injustiças sociais, fez surgir o conflito, até hoje insolvido, entre a limitada noção de igualdade jurídica, que de acordo com sua origem liberal francesa preconiza não mais, que a abolição dos privilégios pessoais, e o desejo de igualdade real, isto é, de igualdade de fato entre os homens no meio social, conflito esse que passou a constituir tormento de todo o regime político".

$\mathrm{Na}$ verdade, a preocupação maior da sociedade política do século VIII era livrar a sociedade de um regime político opressor adotando medidas para implantação de um novo modelo de Estado capitalista livre para operar como força motriz do desenvolvimento sócio-econômico, dando a cada um o que e seu por herança ou conquista. Para esta sociedade, a simples criação de uma lei igual para todos e proibindo qualquer forma de privilégios era suficiente para garantir a conquista da igualdade jurídica.

Porém, nenhuma dessas medidas serviu de impedimento para o crescimento das desigualdades havidas dentro daquela sociedade, porque não foram incluídas na pauta de mudanças, medidas que permitissem que as riquezas fossem também distribuídas de forma mais igualitária.

André Hauriou, citado por Siqueira Castro afirma: ${ }^{28}$

“(...) o ideal de igualdade que se conseguiu concretizar no desfecho da revolução vitoriosa foi tão apenas o da isonomia formal e jurídica, portanto sem substância concreta, consistente na simples abolição de privilégios atribuídos à nobreza e ao clero (...)".

\section{2 - O Princípio da Igualdade nas Constituições brasileiras}

O constitucionalismo brasileiro sempre adotou o Princípio da Igualdade em suas cartas, não significa, porém, que houve sempre respeito e acatamento a ele, mesmo na sua acepção formal. Tanto que na sua primeira fase, ainda no

\footnotetext{
${ }^{28}$ Ibid. 39 p.
} 
governo imperial, esse documento coexistiu com a mancha sócio-política considerada a mais perversa da história do Brasil, a escravidão. A Carta Imperial de 25 de março de 1824 estabeleceu, em seu art. 179, itens 13 a 17, o princípio da igualdade como uma das colunas normativas sustentadoras do sistema posto, ali se assegurando a igualdade da lei para todos, quer protegendo, quer castigando, e recompensando na proporção dos merecimentos a cada um; garantido a acessibilidade dos cidadãos aos cargos públicos sem outra diferença que não fosse a dos talentos e virtudes de cada um; estabelecendo a abolição de todos os privilégios "que não forem essencial e inteiramente ligados aos cargos por utilidade pública e o foro privilegiado e as comissões especiais nas causas cíveis ou crimes, ressalvando-se as causas que, por sua natureza, pertencesse a juízos particulares e preceituando-se a obrigatória contribuição de todos para as despesas do Estado em proporção dos haveres de cada contribuinte".

A Constituição Imperial, bem elaborada e considerada avançada, se de um lado colhe o princípio da igualdade com operacidade e eficácia definida, especialmente quanto à isonomia no acesso aos cargos públicos, aos encargos perante o Poder Público, à jurisdição, por outro lado, a escravidão fez-se pano de fundo das relações sociais fundamentalmente pela Carta mencionada e pedra de toque do sistema econômico vigente à época, contraditando com a igualdade apregoada no texto constitucional. $^{29}$

A Constituição Republicana trouxe inovações no texto da disposição que continha o principio, consoante com o ideário igualitário do novo regime. A República brasileira proclamada em 1889 foi em parte, eco jus-político da abolição da escravatura no ano precedente. A primeira Lei Magna republicana brasileira de 1891 , em seu art. $72, \S 2^{\circ}$ definiu que "todos são iguais perante a

\footnotetext{
${ }^{29}$ Ibid. 62-63 p.
} 
lei”. Inadmitidos privilégios de nascimento e desconhecidos foros de nobreza. A Constituição de 1934 afirmou mais uma vez o princípio da igualdade modificando apenas a redação na parte relativa à vedação de privilégios e distinções, por motivos de nascimento, sexo, raça, profissões, classe social, riqueza, crenças religiosas ou idéias políticas. A Carta de 1937 pela sua forma de "Constituição nominal" não mereceu grandes estudos pelos constitucionalistas, simplificou os termos da disposição sobre a igualdade, deixando preceituado em seu art. 122, $\S 1^{\circ}$, que "todos são iguais perante a lei”. O constitucionalismo brasileiro reaparece em 1946 com a promulgação da Magna Carta por uma Assembléia Nacional Constituinte com a reencampação das idéias que tinham sido objeto de tratamento pelos constituintes de 33/34. Porém, no que concerne ao princípio da igualdade, esta repetiu a mesma redação do art.141, $\S 2^{\circ}$ da anterior.

A mudança do antigo e ultrapassado Estado Liberal para o Social e graças ao grande avanço da doutrina, o princípio da igualdade passa por uma transformação em seu conteúdo, atribuindo-se lhe o sentido de obrigação a ser observada, estrita e incontornavelmente, pelo legislador, tanto quanto pelo administrador e pelo julgador.

A Carta de 1967 , em seu art. $150, \S 1^{\circ}$, outorgada pelo bastião dos militares que assumiram o exercício do poder em 1964, dedicou-se ao princípio em foco, fazendo retornar ao texto normativo a vedação à distinção preconceituosa, especialmente aquelas a que ele se refere sexo, raça, trabalho, credo religioso e convicções políticas, acentuando-se que o preconceito de raça seria punido pela lei. A denominada Constituição AFONSO ARINOS DE MELLO FRANCO não atendeu aos interesses do grupo que detinha o poder, assim, em 1969 foi emendada com a denominada "Emenda Constitucional n ${ }^{\circ}$ 1" de 17 de Outubro de 1969, foi, tecnicamente uma nova Carta Outorgada e por ela, como ensina o ilustre constitucionalista, visava-se apenas a "dar 
visionomia jurídica a um regime de poder de fato". O art. $153, \S 1^{\circ}$, repetindose uma vez mais, a redação dada pelo diploma de 1967.

Mais uma vez, a incidência de uma nova Constituição-Emendada não diminuiu as desigualdades sócio-econômicas existentes no Brasil por força de uma estrutura organizada em estamentos dispostos em detrimento dos menos aquinhoados materialmente a desigualdade, acentuou-se em todos os níveis. Esse Diploma Legal ficou em vigência até 05 de outubro de 1988, quando foi promulgada a Constituição atual elaborada por uma Assembléia Nacional Constituinte eleita pelo povo em um quadro histórico de nova ordem democrática.

A Constituição de 1988, promulgada sob o auspício de uma proposta democrática, dá testemunho de um período de reformulação que se inicia sob um regime político de força e uma sociedade injusta que desiguala em bases arbitrárias e muitas vezes perversa e busca um modelo renovador alicerçado no Direito que tenha como finalidade a recomposição de uma sociedade assentada em um novo alicerce jurídico.

A nova Constituição da República refere-se à igualdade já em seu Preâmbulo onde se definem os valores que nortearam os constituintes na sua elaboração. Estabelece que os representantes do povo por este, eleitos reuniram para instituir um Estado Democrático de Direitos, destinados a assegurar o exercício dos direitos sociais e individuais, a liberdade, a segurança, o bem estar, o desenvolvimento, a igualdade e a justiça como valores supremos de uma sociedade fraterna, pluralista e sem preconceitos. A força jurídica do Preâmbulo se mostra pela dinâmica da Carta ao qual ele se integra com a promulgação. A hermenêutica das normas jurídicas que a compõem é traçada segundo a principiologia posta no preâmbulo e, em caso de dúvidas, prevalece a interpretação mais consoante com os princípios e fins assentados na Lei 
Maior. Razões históricas presentes na composição da República Brasileira fizeram com que se colocasse a igualdade no Preâmbulo da Constituição como princípio determinante da elaboração que a seguir é posta como sistema normativo fundamental. ${ }^{30}$

As normas de maior expressão na Constituição de 1988 estão contidas no art. $5^{\circ}$, onde os direitos e garantias individuais e coletivos se espraiam como garantidores do sistema jurídico brasileiro, e logo de início define a igualdade de todos perante a lei. Diz o art. $5^{\text {o }}$ "todos são iguais perante a lei, sem distinção de qualquer natureza, garantindo-se aos brasileiros e os estrangeiros residentes no País a inviolabilidade do direito à vida, à liberdade, à igualdade, à segurança e à propriedade".

A determinação de que não haverá distinção de qualquer natureza não significa, evidentemente, que haverá uniformização de tratamento jurídico, mas que fator discriminatório algum é válido quando o seu fundamento for o preconceito ou a aversão. Como deve se observar, não se dá a negativa absoluta de que sexo, raça, cor, idade ou credo religioso sejam fatores de desigualação. O que é absolutamente negada é a utilização válida de qualquer um deles em razão de juízo anteriormente formado e sem qualquer correlação lógica, relacional e imediata com o interesse protegido pelo sistema.

A leitura correta do princípio da igualdade preceituado no art. $5^{\circ}$, se faz com a conjugação de outras normas que tratam a igualdade não só no sentido jurídico formal, mas também, no seu sentido material como as regras que proíbem as distinções fundadas em certos fatores, as do art. $3^{\circ}$, preceitua que um dos objetivos fundamentais da República Federativa do Brasil é reduzir as desigualdades sociais e regionais, repulsa a qualquer forma de discriminação, a universalidade da seguridade social, a garantia ao direito à saúde, à educação

\footnotetext{
${ }^{30}$ Ibid. 67 p.
} 
baseada em princípios democráticos e de igualdade de condições para o acesso e permanência na escola, enfim a preocupação com a justiça social como objetivo das ordens econômica e social (arts. 170, 193, 196 e 200), ou seja, regras que constituem reais promessas de busca da igualdade material.

\section{3 - Igualdade formal, material e a questão da desigualdade}

A afirmação do art. $1^{\mathrm{o}}$ da Declaração dos Direitos do Homem e do Cidadão gravou o princípio de que os homens nascem e permanecem iguais em direito. Como ensina José Afonso da Silva, ${ }^{31}$ essa apenas firmou a igualdade no plano jurídico-formal no plano político, de caráter puramente negativo, visando a abolir os privilégios, isenções pessoais e regalias de classe. Esse tipo de igualdade gerou desigualdades econômicas, porque fundadas "numa visão individualista do homem, membro de uma sociedade liberal relativamente homogênea".

As desigualdades e discriminações provocadas por um princípio isonômico oriundo do liberalismo de visão nitidamente individual, fez com que no século XIX, embutisse nos pensadores, legisladores e políticos da época a idéia de igualdade no ideal de prevalente da liberdade, de maneira a exigir do Estado uma atitude de omissão ou parcimônia na regulação da economia, que deveria organizar-se de acordo com a lei natural do laissez faire, laissez passer. Daí porque não se impuseram à entidade estatais ações positivas, concretas com vistas a corrigir as desigualdades existentes no meio social. A preocupação real e a busca pela igualdade material ou de fato começou a existir, somente a partir do século XX, com o advento das constituições socialistas e em algumas neoliberais, a exemplo da mexicana, de 1917, da

\footnotetext{
${ }^{31}$ SILVA, José Afonso da, Curso de Direito Constitucional Positivo. 22a ed. São Paulo: Malheiros Editores ltda. 2003. p.214.
} 
alemã, de Weimer, de 1919, da soviética, de 1923, e da italiana, de 1947, entre outras. $^{32}$

No direito estrangeiro quando se trabalha com a idéia de isonomia no plano jurídico formal, existe uma clara distinção quando se trata da definição do princípio da igualdade perante a lei e o da igualdade na lei. Para o Ordenamento Jurídico Estrangeiro a expressão "igualdade perante a lei" corresponde à obrigação de aplicar as normas jurídicas gerais aos casos concretos, na conformidade com o que elas estabelecem, mesmo se delas resultar uma discriminação, qual seja, uma exigência feita a todos aqueles que aplicam as normas jurídicas, enquanto que a "igualdade na lei"exige que nas normas jurídicas, não haja distinções que não sejam autorizadas pela própria constituição, neste caso, a exigência se dirige tanto para os criadores das normas jurídicas gerais, quanto àqueles que as aplicam nos casos concretos. Dentro do ordenamento jurídico brasileiro tanto a orientação jurisprudencial como doutrinária, resta pacificado que a "igualdade perante a lei" tem o mesmo sentido que se dá no exterior da expressão "igualdade na lei”, ou seja: o princípio tem como destinatários tanto o legislador como os aplicadores da lei. $^{33}$

Cabe afirmar, no entanto, que diante das transformações ocorridas dentro da sociedade moderna, pela mudança mundial da ordem econômica, política e social, o princípio da igualdade não pode mais ser entendido no sentido individualista, que não leve em conta as diferença dos grupos formadores da sociedade. Mesmo se reconhecendo que em essência, como seres humanos os homens sejam iguais, não se pode também desconhecer que existem inúmeras desigualdades como: naturais, físicas, morais, políticas,

\footnotetext{
${ }^{32}$ Ibid. 37,38 p.

${ }^{33}$ SILVA, José Afonso da, Curso de Direito Constitucional Positivo. 22 $2^{\mathrm{a}}$ ed. São Paulo: Malheiros Editores ltda. 2003. 214 p.
} 
sociais etc. Existem desigualdades, as naturais, que são consideradas saudáveis e aquelas ruins, as sociais e econômicas.

O eminente jurista, Celso Antônio Bandeira de Mello, em sua famosa obra, O conteúdo Jurídico do Princípio da Igualdade citando Hans Kelsen afirma:

"A igualdade dos sujeitos na ordenação jurídica,
garantida pela Constituição, não significa que estes
devam ser tratados de maneira idêntica nas normas e
em particular nas leis expedidas com base na
Constituição. A igualdade assim entendida não é
concebível: seria absurdo impor a todos os indivíduos
exatamente as mesmas obrigações ou lhes conferir os
mesmos direitos sem fazer distinção alguma entre eles,
(...)".

O conceito de igualdade sempre provoca posições extremadas de doutrinadores, filósofos, juristas e todos aqueles que de alguma forma contribuem na evolução histórica das sociedades. Existem algumas teorias que falam sobre o assunto. Porém duas dela se destacam: a teoria nominalista sustenta que a desigualdade é característica do universo, contrariando assim, a afirmativa do art $1^{\circ}$ da Declaração dos Direitos do Homem e do Cidadão de 1789, para esses teóricos os homens nascem e perduram desiguais. A igualdade não passaria de um simples nome, essa é a denominada corrente nominalista. Oposta a esta, encontra-se a corrente idealista que afirma um igualitarismo absoluto entre as pessoas, afirma na verdade uma igual liberdade natural ligada à hipótese do estado de natureza, em que reinava um estado de igualdade absoluta.

A corrente realista comunga da idéia de Rousseau, ele admitia duas espécies de desigualdades entre o homem: uma, que chamava de natural ou física, porque estabelecida pela natureza, consistente na diferença das idades, da saúde, das forças do corpo e das qualidades do espírito e da alma; a outra, 
que denominava desigualdade moral ou política, porque depende de uma espécie de convenção, e é estabelecida ou ao menos autorizada, pelo consentimento dos homens, consistindo nos diferentes privilégios que uns gozam em detrimento dos outros, como ser mais ricos, mais nobres, mais poderosos. Afirma José Afonso da Silva, citando Locke. ${ }^{34}$

Com relação aos critérios erigidos pela lei como fator de do tratamento igualitário, o eminente jurista Celso Antônio Bandeira de Mello afirma: ${ }^{35}$

\footnotetext{
"É agredida a igualdade quando o fator diferencial adotado para qualificar os atingidos pela regra não guarda relação de pertinência lógica com a inclusão ou exclusão no benefício deferido ou com a inserção ou arredamento do gravame imposto. (...) $\mathrm{O}$ fator de discriminação pode ser qualquer elemento radicado neles, todavia, necessita inarredavelmente guardar relação de pertinência lógica com a diferenciação que dele resulta".
}

Hoje, uma análise do Principio da Igualdade para ser completa deve ser feita conjuntamente com dois importantes valores que sem estes, se torna impossível manter a harmonia dentro de uma sociedade: a liberdade e a justiça.

Igualdade, liberdade e justiça se completam na medida em que o homem para ser considerado como pessoa deve ser, enquanto indivíduo singular, livre; enquanto ser social deve estar com os demais indivíduos numa relação de igualdade, onde deve imperar os mais amplos esforços para a realização da justiça. Juntas devem formar um todo harmônico em perfeito equilíbrio.

\footnotetext{
${ }^{34}$ Ibid. p. 211

${ }^{35}$ Ibid. p. 49
} 


\section{Capítulo III}

\section{O Ingresso da Mulher no Mercado de Trabalho}

Desde a antiguidade a mulher se faz presente no mercado de trabalho, a história registra que na antiguidade, mais precisamente no Egito, a tecelagem era uma ocupação reservada às mulheres. Competia a elas tosquiar as ovelhas e tecer a lã. Trabalhavam também na ceifa do trigo e no preparo da farinha e na massa do pão, as mulheres mais pobres trabalhavam nas grandes obras das construções. No antigo Egito as mulheres não eram consideradas como um ser inferior provavelmente por eles não ter grandes preocupações com a questão militar tanto que algumas mulheres desempenhavam papel político na sociedade dentre essas mulheres pode-se destacar o reinado de Uatshepsut em meados do segundo milênio. ${ }^{36}$

$\mathrm{Na}$ sociedade cretense as mulheres ocupavam cargos de destaque cabendo às sacerdotisas o papel principal nas cerimônias religiosas, a história mostra mulheres em teatros, arenas circenses e em praças públicas daí se conclui que nessa sociedade elas gozavam de certa liberdade. Já a civilização grega, no período clássico, as elas não tinha grandes espaços, o saber era restrito aos homens e poucas mulheres, diferentemente da civilização helenística onde elas tinham acesso à literatura e às artes.Na Grécia antiga enquanto a maioria das mulheres teciam, moíam trigo e preparavam a massa para que os homens fabricarem o pão, já que este era considerado trabalho tipicamente masculino, uma minoria delas faziam trabalhos pesados nas minas de prata e ferro, separando e transportando mineral. Entre os séculos X e XIV as profissões comuns aos dois sexos tem um grande crescimento, tanto os homens quanto às mulheres exerciam profissões como: escrivãos, médicos e

\footnotetext{
${ }^{36}$ Ibid. p. 27.
} 
professores e, curiosamente, os salários entre os dois sexos não se distanciavam tanto.

No renascimento, as mulheres vão gradativamente perdendo suas atividades para os homens e passam a ser confinadas dentro do lar, primeiro o trabalho com seda, materiais preciosos, com a cerveja e com as velas e, posteriormente, com a miséria nos campos, perdem o trabalho dentro das fábricas. Somente a partir do século XIX com o crescimento da indústria têxtil na França e Inglaterra, a mão-de-obra feminina e do menor passa a ser solicitada por ser considerada mais "dócil" e menos dispendiosa.

Se lançarmos um olhar observador pelas civilizações passadas, diante do que foi escrito, depreendemos que nessa época as mulheres não eram consideradas força de trabalho, pois este era considerado fonte de sobrevivência da sociedade e não como um dos principais fatores para o crescimento e desenvolvimento econômico como é visto na modernidade.

O ingresso no mercado de trabalho se dá em larga escala com o desenvolvimento do capitalismo nascido a partir da Revolução Industrial. Com o capitalismo surge um novo sistema econômico calcado em grandes unidades de produção exigindo um grande volume de mão-de-obra.

Dois motivos contribuíram para o ingresso das mulheres na industria manufatureira: em primeiro lugar, era interessante para os empresários ávidos por lucros cada vez maiores, empregar mulheres e crianças, por constituírem mão-de-obra extremamente barata; em segundo lugar, os homens substituídos por mulheres em seus empregos foram "invadindo" as vagas entes ocupadas 
pelas mulheres criando assim uma espécie de "círculo vicioso", uma inversão de papéis. ${ }^{37}$

$\mathrm{O}$ ingresso da mulher na força produtiva foi um marco histórico de grande importância, pois, colocou em evidência a situação da mulher na sociedade. A discriminação, a exploração, o desrespeito, o tratamento desumano sofrido por elas, no trabalho foi apenas o reflexo da condição feminina desde os primórdios da humanidade, onde a mulher era tratada como ser inferior, com papel restrito na sociedade. Dentro das indústrias têxteis a jornada de trabalho atingia até 14 horas diárias em troca de salários inferiores aos recebido pelos homens à exploração atingiu tamanha proporção que obrigou as autoridades a adotarem medidas de proteção à mulher, não que estivessem de fato, sensibilizados com a condição da mulher, a preocupação maior, era de que toda essa situação poderia provocar desemprego em massa entre os homens, estimulando uma revolta, colocando em risco o modelo político-econômico capitalista. ${ }^{38}$

Dessa época até os dias atuais foram muitas as mudanças na situação da mulher na sociedade, grande parte dessas mudanças se deve a luta feminina pela sua liberdade, igualdade social, cultural política e jurídica. Durante longo tempo, as estruturas sociais restringiram ou impediram o desenvolvimento da mulher, o que explica o fato do homem ter-se destacado mais que ela no setor intelectual. Mas isso não significa que existem diferenças nesse campo, e as aptidões naturais de um e de outro sexo decorrem exclusivamente de fatores de ordem física e emocional. ${ }^{39}$ As conquistas foram muitas, porém, a tão sonhada igualdade entre homens e mulheres continua sendo uma meta difícil de ser

\footnotetext{
${ }^{38}$ CF. VIANNA, Segadas. Instituições de Direito do Trabalho. $17^{\mathrm{a}}$ edição. São Paulo: LTR. 1997, p. 951

${ }^{39}$ VIII Conferência Nacional da Ordem dos Advogados do Brasil - Manaus - Maio, 1980
} 
alcançada, pois implica em mudanças de antigos conceitos e fatores, sedimentados desde o princípio da humanidade.

Hoje, século XXI, existe ainda um longo caminho para ser percorrido. A discriminação contra a mulher permanece como forte impedimento ao desenvolvimento social, cultural, criativo e político, muitas continuam sendo vítimas de todo tipo de violência e preconceitos, principalmente aquelas que sofrem a dupla discriminação. A abordagem seguinte, mostra como a discriminação pode afetar um seguimento social a ponto de deixá-lo a margem da sociedade.

O mercado de trabalho vai servir de parâmetro para mostrar neste trabalho como no Brasil a discriminação racial serviu de barreira à ascensão econômica e social do negro ou mais especificamente da mulher negra.

\section{1 - A Situação da Mulher Negra Brasileira no Trabalho}

A situação da mulher negra no Brasil de hoje mostra o prolongamento da sua realidade vivida no período da escravidão com poucas mudanças. Ela carrega as desvantagens do sistema injusto e racista existente no nosso país, de acordo com as pesquisas mais recentes elas fazem parte do grupo social que apresentam o menor nível de escolaridade, jornada de trabalho maior sem que isso se traduza em maiores rendimentos, ao contrário, são destinados a elas os menores salários. Poucas dessas mulheres conseguem vencer as barreiras da discriminação e do preconceito e ascender socialmente quando conseguem carregam sobre si o ônus de terem abdicado dos sonhos de casar e ser mãe, pois para se realizar profissionalmente e socialmente o esforço despendido faz com que ela tenha que escolher o sonho ou a profissão.

O Brasil, cuja construção e desenvolvimento se deve em grande parte a mão-de-obra escrava que, por mais de quatro séculos foi a principal força de 
trabalho, relegou o seu principal agente construtor, o negro, a um passado e presente de miséria, sem condições dignas de sobrevivência, reflexo da falsa abolição. O maior dos males foi retirar do negro a sua identidade enquanto raça remetendo a questão da sua negritude aos porões da sociedade, por isso a luta principal do movimento negro é pelo resgate da cidadania do negro.

A pobreza e a marginalidade a que está submetida a mulher negra reforça o preconceito e a interiorização da condição de inferioridade que a inibe de lutar contra a discriminação sofrida, a despeito dessa situação algumas mulheres já vem se despertando para a luta em favor da igualdade de fato pois, além da origem escrava, ser negra no Brasil constitui um empecilho na busca da cidadania e da ascensão social.

O ingresso da mulher negra no mercado de trabalho brasileiro, dar-se-á ainda criança, pois, muito cedo ela aprende que a luta pela sobrevivência será de forma desigual se comparado aos outros seguimentos da sociedade. Os baixos salários e a colocação nos cargos menos qualificados reforçam neles o estigma da inferioridade. Para conquistarem melhores colocações no mercado de trabalho, como afirmamos anteriormente, elas despendem esforço muito maior que outros setores da sociedade, pagando um preço alto pela conquista. Maria Nilza da Silva, Professora no Departamento de ciências Sociais da Universidade Estadual de Londrina, afirma: ${ }^{40}$

\footnotetext{
"Na atualidade não se pode tratar a questão racial como elemento secundário, destacando apenas a problemática econômica. A posição social do negro não se baseia apenas na possibilidade de aquisição ou consumo de bens. Ainda há uma grande dificuldade brasileira em assumir a questão racial como um problema que necessita ser enfrentado. Enquanto esse processo de enfrentamento não ocorrer, as desigualdades sociais baseadas na discriminação racial
}

\footnotetext{
${ }^{40}$ SILVA, Maria Nilza da. A Mulher Negra. Disponível em www.espacoacadêmico.com.br. acesso em 20 abr. 2005.
} 
continuarão, e, com tendência ao acirramento, ainda mais quando se trata de igualdade de oportunidades em todos os aspectos da sociedade."

Não se pode negar que a discriminação racial da população negra no Brasil é evidente e constante, enfrentar a questão é tarefa árdua, principalmente se partirmos do pressuposto que até bem pouco tempo se acreditava na falsa idéia ou no mito da "democracia racial".

\section{2 - A questão Racial Como Fator Preponderante na Desigualdade de Acesso ao Mercado de Trabalho}

A discriminação existe em toda sociedade e de várias formas: social, religiosa, de gênero, étnica, e muitas outras. No Brasil, durante anos, acreditava-se que na sociedade brasileira existia uma convivência harmoniosa e feliz, e que entre nós havia uma perfeita integração entre credos, raças, admitindo-se apenas o preconceito de gênero e social. Por isso, a questão racial foi sendo relegada, hoje, quando se coloca em debate a questão da discriminação racial ou o preconceito racial, quando o assunto é colocado em discussão provoca vários tipos de reação: uns optam pelo silêncio, outros a negação, alguns confirmam a existência, mas, que a questão não é grave ou ainda na opinião da grande maioria existe no Brasil um preconceito muito forte contra o seguimento social de classe baixa, dos menos favorecidos, e, como os negros em grande maioria fazem parte desse seguimento, são eles os mais atingidos por esse tipo de preconceito.

Não se pode negar que o preconceito social na sociedade brasileira existe e, é muito forte, porém, aliado a este, existe o preconceito de raça que condena homens e mulheres negros a um permanente estado de exclusão social como demonstram recentes pesquisas resultantes de estudos relacionados ao assunto. 
Nos estudos realizados pelo Ministério do Trabalho e Emprego do Governo Federal, mostra que o Brasil possui a segunda maior população negra do mundo, superado apenas pela Nigéria, País da África. De acordo com o IBGE (Instituto Brasileiro de Geografia e Estatística), em 1997, através da Pesquisa Nacional Por Amostra e Domicílios - PNAD- a população brasileira somava 156.128.003, dos quais 45\% declararam-se negros e pardos. No entanto, apesar da grande representatividade da raça negra na população brasileira, a presença da reprodução da desigualdade racial, sociopolítica, econômica e cultural permanece significativamente nesse seguimento populacional.

Quando se trata de inserção no mercado de trabalho, o negro, principalmente as mulheres sofrem um brutal processo de exclusão que vem desde o tempo da escravatura até os dias atuais. Na década de 80 o sociólogo Clóvis Moura, através de dados pesquisados no SINE (Sistema Nacional de Empregos) - SINEP/SP, órgão do Ministério do Trabalho, denunciava essa mesma discriminação por parte de diversas empresas. ${ }^{41}$ "O direito básico de qualquer cidadão (direito ao trabalho) é, assim, continuamente, dificultado ao negro, em conseqüência da discriminação "preconceituosa" de muitos empregadores".

$\mathrm{Na}$ área educacional a desigualdade racial se revela expressiva, pois, enquanto a taxa de analfabetismo entre os brancos é de $9 \%$, entre os afrodescendentes é de $22 \%$. Com relação ao ensino médio, os brancos atingem seis anos em média, e os negros, cerca de quatro anos. Isso implica que, em cerca de $7 \%$ de negros, encontram-se nas escolas até o $1^{\circ}$ grau e $3 \%$ cursam o $2^{\circ}$ grau. Em relação ao curso superior a realidade não difere das outras etapas da vida escolar, $2 \%$ dos negros freqüentam a faculdade, enquanto entre os brancos

\footnotetext{
${ }^{41}$ SÉRIE CADERNOS TEMÁTICOS. A Experiência dos afro-brasileiros. V. Nirema- PUC-Rio. Brasília: 1999/2000. p. 12/13.
} 
o percentual é de $80 \%$. O estudo revela que embora a educação formal seja um dado importante para abrandar as desigualdades, mostra no entanto, não ser suficiente, uma vez que entre um negro e um branco de igual nível de escolaridade, o negro receberá salário inferior como mostra a tabela abaixo: ${ }^{42}$

\section{TABELA I}

Diferenças Salariais entre Chefes de Família com mais de 12 Anos de Estudo.

\begin{tabular}{|c|c|c|c|}
\hline $\begin{array}{c}\text { HOMEM } \\
\text { BRANCO }\end{array}$ & $\begin{array}{c}\text { HOMEM } \\
\text { NEGRO }\end{array}$ & $\begin{array}{c}\text { MULHER } \\
\text { BRANCA }\end{array}$ & $\begin{array}{c}\text { MULHER } \\
\text { NEGRA }\end{array}$ \\
\hline $\mathbf{8 8 1 , 0 0}$ & 559,00 & 423,00 & 266,00 \\
\hline
\end{tabular}

A pesquisa revela outros dados. A mulher negra sofre dois tipos de discriminação, a étnica e de gênero: com relação a pesquisa realizada em 1998, sobre seis regiões metropolitanas, a participação feminina negra situa-se de forma expressiva na área de serviços domésticos.

\section{TABELA II}

Mapa da População Negra no Mercado de Trabalho - Diferenças Salariais 1998

\begin{tabular}{|c|c|c|c|c|}
\hline $\begin{array}{c}\text { REGIÕES } \\
\text { METROPOLITANAS }\end{array}$ & $\begin{array}{l}\text { HOMEM } \\
\text { BRANCO }\end{array}$ & $\begin{array}{l}\text { HOMEM } \\
\text { NEGRO }\end{array}$ & $\begin{array}{l}\text { MULHER } \\
\text { BRANCA }\end{array}$ & $\begin{array}{l}\text { MULHER } \\
\text { NEGRA }\end{array}$ \\
\hline SÃO PAULO & R\$ 1.188,00 & R\$ 601,00 & R\$ 750,00 & R\$ 399,00 \\
\hline SALVADOR & R\$ $1.051,00$ & R\$ 498,00 & R\$ 647,00 & R\$ 297,00 \\
\hline RECIFE & R\$ 739,00 & R\$ 427,00 & R\$ 462,00 & R\$ 272,00 \\
\hline $\begin{array}{l}\text { DISTRITO } \\
\text { FEDERAL }\end{array}$ & R\$ 1.306,00 & R\$898,00 & R\$ 923,00 & R\$ 614,00 \\
\hline
\end{tabular}

\footnotetext{
42 Ibid. p.14/15.
} 


\begin{tabular}{|c|c|c|c|c|}
\hline & & & & \\
\hline BELO HORIZONTE & R\$ 883,00 & R\$ 670,00 & R\$ 548,00 & R\$ 319,00 \\
\hline & & & & \\
\hline PORTO ALEGRE & R\$ 715,00 & R\$ 472,00 & R\$ 504,00 & R\$ 334,00 \\
\hline
\end{tabular}

A terceira tabela mostra um dado revelador. Os resultados das pesquisas trazem um conjunto de informações que demonstram uma situação reiterada de desigualdade para os trabalhadores e trabalhadoras afro-brasileiros(as) no mercado de trabalho das seis regiões já referidas. Os resultados permitem concluir que a discriminação racial sobrepõe-se à discriminação por sexo, combinando-se a esta para constituir o cenário da aguda dificuldade em que vivem as mulheres negras, duramente atingidas por ambas.

TABELA III

Índice do Rendimento Mensal Segundo Raça e Sexo

\begin{tabular}{|c|c|c|c|c|}
\hline & $\begin{array}{c}\text { MULHERES } \\
\text { NEGRAS }\end{array}$ & $\begin{array}{l}\text { HOMENS } \\
\text { NEGROS }\end{array}$ & $\begin{array}{c}\text { MULHERES } \\
\text { BRANCAS }\end{array}$ & $\begin{array}{l}\text { HOMENS } \\
\text { BRANCOS }\end{array}$ \\
\hline $\begin{array}{c}\text { BELO } \\
\text { HORIZONTE }\end{array}$ & 36,15 & $62,1 \%$ & $75,9 \%$ & $100,0 \%$ \\
\hline $\begin{array}{l}\text { DISTRITO } \\
\text { FEDERAL }\end{array}$ & $47,0 \%$ & $68,8 \%$ & $70,7 \%$ & $100,0 \%$ \\
\hline $\begin{array}{c}\text { PORTO } \\
\text { ALEGRE }\end{array}$ & $46,7 \%$ & $66,0 \%$ & $70,5 \%$ & $100,0 \%$ \\
\hline RECIFE & $36,8 \%$ & $68,8 \%$ & $70,7 \%$ & $100,0 \%$ \\
\hline SALVADOR & $28,3 \%$ & $47,4 \%$ & $63,1 \%$ & $100,0 \%$ \\
\hline SÃO PAULO & $33,6 \%$ & $50,6 \%$ & $62,5 \%$ & $100,0 \%$ \\
\hline
\end{tabular}

A questão racial no Brasil é complexa, enquanto o negro não tinha consciência da sua cidadania e se manteve pacificamente no "lugar" que a sociedade julgava ser ele merecedor o mito da "democracia racial" se manteve inabalado. A partir do momento que os conscientiza e sai em busca da 
igualdade de fato o mito não resiste ao confronto com a realidade. Ante a constatação de que a sociedade brasileira como qualquer outra não está e nunca esteve imune ao mal da discriminação e do preconceito, dá-se início a etapa mais complexa, discutir a questão racial. Nesse momento o movimento negro terá que enfrentar outras questões e mito não menos poderoso que o anterior que povoa as idéias da classe dominante, de que no Brasil existe de fato a discriminação social e não racial e como o seguimento discriminado é composto na maioria por negros, estes são os grandes prejudicados com esta situação.

No entanto, as pesquisas acima mostram que a idéia da discriminação social como fator preponderante da marginalização do negro pela sociedade brasileira também é falsa, pois não explica o fato de quando alguns negros e negras depois de muita luta se destacar intelectualmente não conseguem competir em igualdade de condições com os brancos de mesmo nível intelectual em termos de cargo, salário, não explicam também, na medida em que o negro se destaca o grau de dificuldade aumenta até se tornar uma barreira quase intransponível para a sua ascensão.

No próximo capítulo será destacado e o que vem sendo feito em vários Países em termos de políticas públicas para tornar possível a inclusão de negros e outras minorias dentro das sociedades desenvolvidas. 


\section{CAPÍTULO IV}

\section{Igualdade e Ação Afirmativa}

Antes da década de 60 não havia a preocupação de se promover a igualdade entre os indivíduos de uma mesma sociedade. A partir da Segunda Grande Guerra com as nações empobrecidas criou-se um ambiente perfeito para o crescimento das intolerâncias raciais, religiosas, contra deficientes físicos psíquicos e mulheres. Nesse quadro caótico de marginalização e exclusão de enormes seguimentos sociais provocados pelas desigualdades e discriminações os países denominados Estados Democráticos de Direito promulgaram novas constituições incluindo nelas capítulos dedicados aos direitos humanos e normas garantindo a liberdade, igualdade e dignidade humana para todos e, proibindo todas as formas de discriminação.

A despeito dessas normas as desigualdades não foram superadas, restou evidente que juntamente com estas, outras medidas teriam que ser tomadas, apenas a lei não garante as mudanças. Tem que haver um comprometimento de toda a sociedade civil e do governo com políticas públicas para transformar essa situação.

Nesse momento, década de 60, surge um instrumento denominado: Ação Afirmativa. A expressão ação afirmativa, ${ }^{43}$ utilizada pela primeira vez numa ordem executiva federal norte-americana, em 1965, passou a significar desde então, a exigência de favorecimento de algumas minorias socialmente inferiorizadas, vale dizer, juridicamente desigualadas, por preconceitos arraigados culturalmente e que precisavam ser superados para que se atingisse

\footnotetext{
${ }^{43}$ ROCHA, Carmen Lúcia Antunes. O Princípio da Igualdade e a Ação Afirmativa no Direito. Revista Trimestral de Direito Público. 15/1996. p.87.
} 
a eficácia da igualdade preconizada e assegurada constitucionalmente na principiologia dos direitos fundamentais ${ }^{44}$.

Nos Estados Unidos, onde são aplicadas desde a década de sessenta, pretendem oferecer aos afro-americanos as chances de participar da dinâmica da mobilidade crescente. No mercado de trabalho os empregadores foram obrigados a mudar suas práticas, planificando medidas de contratação, formação e promoção nas empresas visando a inclusão dos afro-americanos; as universidades foram obrigadas a implantar políticas de cotas e outras medidas favorecendo a população negra; os órgãos publicitários e empresas de comunicação e a mídia foram obrigados a reservar em seus programas uma certa percentagem para a participação dos negros. No mesmo momento, programas de aprendizado de tomada de consciência racial foram desenvolvidos a fim de levar a reflexão aos americanos brancos na questão do combate ao racismo.

$\mathrm{Na}$ verdade, a política da ação afirmativa é uma proposta de discriminação positiva ou política compensatória, qual seja, tratar os desiguais na medida em que se desigualam. Com isso, todas as pessoas sendo físicas ou jurídicas e indivíduos que se enquadram no conceito de minorias e sofrem com as discriminações existentes passam a ser sujeitos da ação afirmativa $\mathrm{Na}$ esteira do movimento da ação afirmativa reside o pensamento de que o Direito Constitucional, posto em aberto, deve ser mutante e mutável para se fazer permanentemente adequado às demandas sociais, não pode persistir no conceito estático de um direito de Igualdade proto, realizado segundo parâmetro históricos eventualmente ultrapassados. Daí a necessidade de se pensar a igualdade jurídica como a igualação jurídica que se faz, constitucionalmente, no compasso da história, do instante presente e da

\footnotetext{
${ }^{44}$ ROCHA, Carmen Lúcia Antunes. Ação Afirmativa- O Conteúdo Democrático do Princípio da Igualdade Jurídica.Revista Trimestral de Direito Público. 15/1996. p.87
} 
perspectiva vislumbrada em dada sociedade: a igualdade posta em movimento, em processo de realização permanente; a igualdade provocada pelo Direito segundo um sentido próprio a ela atribuído pela sociedade. ${ }^{45}$

\section{1 - A Política das Cotas como meio de inclusão.}

A despeito das críticas contrárias à política de cotas utilizadas dentro do movimento das ações afirmativas, nos países onde foi implantada a mais de quatro décadas ficou provado através de pesquisas que houve uma melhoria significativa no padrão de vida das pessoas beneficiadas por essa política. Nos Estados Unidos, um dos primeiros países a adotar o regime de cotas o crescimento da classe média afro-americana foi de 3\%, um aumento considerável se levarmos em conta que antes da sua adoção os afro-americanos não atingiam pontos necessários para atingir a percentagem e entrar na estatística.

No Brasil, a medida mais conhecida nesse sentido está na Lei 8.112/90 que regula o regime jurídico dos funcionários públicos da União. No art. $5^{\circ}$, parágrafo $2^{\circ}$ da mesma lei $20 \%$ das vagas existente no edital para concursos destinados a preenchimento de cargos públicos ficam reservadas a portadores de deficiência, e algumas iniciativas das quais podemos citar:

- A criação do Grupo de Trabalho Interministerial para a Valorização da População Negra.

- Criação do Grupo de Trabalho para a Eliminação da Discriminação no Emprego e na Ocupação.

- Inclusão do Quesito raça/cor nos sistemas de informação e registro.

- Inclusão dos quesitos raça/cor nos formulários dos treinandos nos cursos do PLANFOR (Plano Nacional de Qualificação do Trabalhador).

${ }^{45}$ Ibid. p. 90 
- Prioridade de acesso aos grupos vulneráveis do PEA aos cursos de qualificação do trabalhador (mulheres chefes de família, jovens em situação de risco social e candidatos ao primeiro emprego, pessoas de etnia afro-brasileira e indígena e de outras minorias étnica, pessoas com necessidades especiais de visão, locomoção, audição e mentais).

- Abertura para a participação de negros e orientais na carreira diplomática, no Itamaraty.

- Reconhecimento oficial do governo brasileiro de Zumbi dos Palmares como herói nacional.

- Apoio à participação de integrantes de grupos étnicos nas propagandas institucionais dos governos federal, estaduais e municipais.

- Divulgação das Convenções Internacionais que tratam da discriminação. ${ }^{46}$

São medidas muito tímidas se comparadas ao estrago moral e o atentado a dignidade humana praticados contra os negros depois de sofrerem por quase quatro séculos a mais cruel escravidão e 116 anos de falsa liberdade.

\section{2 - Polêmicas Acerca da Política de Cotas.}

Qualquer proposta de mudanças em benefício dos excluídos jamais receberá apoio unânime principalmente quando a discriminação racial é apontada no centro da discussão como causa preponderante de exclusão. A primeira questão que se levanta é que faz distinção de tratamento entre as pessoas seja ele qual for a hipótese ou argumento é inconstitucional por ferir o Princípio da Isonomia preceituado Constituição no art. 5º I: “Todos são iguais

\footnotetext{
${ }^{46}$ Série Cadernos Temáticos do Ministério Trabalho e Emprego. A experiência dos Afro-brasileiros. Brasília: 1999/2000, p.20.
} 
perante a lei, sem distinção de qualquer natureza". Com relação a essa questão o iminente jurista Celso Antônio Bandeira de Mello afirma : ${ }^{47}$

“(...) Qualquer elemento residente nas coisas, pessoas ou situações, pode ser escolhido pela lei como fator discriminatório. (...) Basta configurar algumas hipóteses em que estes caracteres são determinantes do discrímen para se aperceber que, entretanto, em nada se chocam com a isonomia".

Portanto o que fere o princípio da isonomia são as desequiparações fortuitas ou injustificadas. Para o jurista, se a lei se propôs distinguir pessoas, situações, grupos, e se tais diferenciações se compatibilizam com os princípios expostos, não há como negar os discrímens. Afirma ainda que: ${ }^{48}$

“(...) A isonomia se consagra como o maior dos
princípios garantidores dos direitos individuais.
"Praeter legem”, a presunção genérica e absoluta é a
da igualdade, porque o texto da Constituição o impõe.
Editada a lei, ai sim, surgem as distinções (que possam
se compatibilizar com o Princípio máximo) por ela
formulada em consideração à diversidade das
situações. Bem por isso, é preciso que se trate de
desequiparação querida, desejada pela lei, ou ao menos
pela conjugação harmônica das leis (...)”.

De conformidade com as lições do autor acima citado, o princípio constitucional da igualdade não é insuperável desde que exista um vínculo de correlação lógica entre "a peculiaridade diferencial acolhida por residente no objeto, e a desigualdade de tratamento em função dela conferida, desde que tal correlação na seja incompatível com interesses prestigiados na Constituição”. Essa afirmação encontra assento na Constituição de 1988 ao inserir no preâmbulo a idéia de que não se tem a democracia social, a justiça social, mas o Direito foi ali elaborado para que se chegue a tê-lo. E, o art. $3^{\circ}$, I, III, IV diz que se constitui objetivos fundamentais da República Federativa do Brasil: construir uma sociedade livre, justa e solidária; erradicar a pobreza e a

\footnotetext{
${ }^{47}$ MELLO, Celso Antônio Bandeira de, O Conteúdo Jurídico do Princípio da Igualdade. ED. RT. São Paulo:1979, p.21/22

${ }^{48}$ Ibid. p. 58.
} 
marginalização e reduzir as desigualdades sociais e regionais; promover o bem de todos, sem preconceito de origem, raça, sexo, cor, idade e quaisquer outras formas de discriminação, isso implica numa ação governamental para a concretização da norma constitucional.

A outra questão reside na idéia de que ao se destinar cotas para as minorias estaria na verdade praticando uma discriminação contra as maiorias que sem ser marginalizadas historicamente estariam perdendo espaços para as minorias. O receio na verdade não se justifica uma vez que os estados ao implantarem as ações de política afirmativa, fixaram essas cotas em percentuais mínimos justamente para que não ocorresse o oposto. À maior parcela das vagas em escolas, empregos e áreas de lazer ficam livres para serem disputadas pela maioria. Até hoje não houve pesquisas apontando quais foram os prejuízos causados à maioria por causa das vagas destinadas às minorias marginalizadas.

No Brasil, respeitando-se as peculiaridades culturais e históricas do racismo aqui praticado, o argumento que pesa em favor das cotas é a situação de marginalização em que se encontra a população negra. Estudando dados do IBGE e do IPEA sobre os indicadores econômicos de renda, emprego, escolaridade, classe social e situação familiar ao longo de 70 anos, chega-se a triste conclusão que a condição racial no Brasil é fator de privilégios de brancos e desvantagens para negros e não-negros: do total dos universitários $97 \%$ são de brancos, $2 \%$ de negros, $1 \%$ de descendentes orientais. Sobre os 22 milhões de brasileiros que vivem abaixo da linha de pobreza, 70\% são de negros, e sobre os 53 milhões de brasileiros que vivem na pobreza $63 \%$ deles são de negros. Deduz-se nessa pesquisa que se o ensino básico e fundamental melhorar seus níveis em 32 anos os negros vão competir em igualdade com os brancos oriundos dos colégios particulares, mas, para isso será necessário que 
os alunos brancos parem e esperem os alunos negros atingirem os mesmos patamares.

A política das cotas também aqui não é aceita pela grande maioria. Uma das críticas diz que é difícil implantar aqui a política de cotas pela dificuldade de se definir quem é negro no Brasil por causa da mestiçagem, isso facilitaria a fraude por parte de alunos brancos que alegando sua descendência afro pelo processo de mestiçagem ocuparia as vagas destinadas às verdadeiras vítimas do racismo. Entendemos que isso não ocorreria uma vez que no Brasil, o ideal do branqueamento é muito forte além do que um racista essencialista é psicologicamente convencido da superioridade da sua raça e não vai trocar de lugar tão facilmente. Outro argumento é o porquê das cotas não serem também destinadas aos índios e sua descendência cujos direitos foram igualmente violados durante séculos, além de serem despojados do seu imenso território. Os movimentos negros que reivindicam cotas nunca foram contra as propostas que beneficiariam as populações indígenas, mulheres, homossexuais, portadores de necessidades especiais, até as classes pobres independentemente da pigmentação da pele. Apenas reivindicam um tratamento diferenciado, tendo em vista que foram e constituem ainda a grande vítima de uma discriminação específica, racial. ${ }^{49}$

Realmente é difícil imaginar que as propostas de ação afirmativa seriam aceitas com passividade em um País onde há pouco tempo se negava os indícios de preconceito étnico e de discriminação racial. Foi difícil para os movimentos negros fazerem com que as autoridades oficiais brasileiras admitissem que esta sociedade é racista. Outro passo importante é desmistificar a idéia de que é difícil lutar contra a discriminação no Brasil porque ela não

\footnotetext{
49 MUNANGA, Kabenguele. Políticas de Ação Afirmativa em Benefício da População Negra no Brasil - Um Ponto de Vista em Defesa das Cotas. www.espacoacademico.com.br/022/22cmunanga.htm. 1999. Disponível em 11/04/05.
} 
tem um rosto definido, é velada, a discriminação pode ser velada, porém as conseqüências causadas por ela são bem visíveis, basta um olhar observador para perceber qual raça compõe em maior número a classe dos miseráveis. Será isso um mero acaso do destino?

A proposta das cotas não é ideal e nem pode ser definitiva, mas, no momento é a que melhor atente a urgência que a situação exige. 


\section{Conclusão}

A escolha do tema discriminação racial no Brasil, objeto do presente trabalho, teve como objetivo discutir uma questão que ainda é polêmica e que toca cada brasileiro negro ou branco que deseja sinceramente construir uma nação livre da miséria da desigualdade e do preconceito, como preceitua a nossa Lei Maior em seu artigo terceiro. Não é um tema confortável de se discutir porque mexe com conceitos e sentimento que cada um quer trazer bem guardado dentro de si, mexe com feridas que julgamos cicatrizadas.

Mas não se pode fechar os olhos para a realidade de miséria, desigualdade e marginalização de todo um povo que sofre e não consegue se desenvolver porque é vítima de uma discriminação odiosa que lhe barra qualquer tentativa de fugir a essa realidade imposta. Os negros que tanto trabalharam para o desenvolvimento do país foram excluídos dos benefícios desse progresso.

É para mudar essa realidade perversa que os movimentos negros se mobilizam para chamar a atenção da sociedade como um todo e exigir das autoridades políticas públicas que lhes garantam o direito a sua identidade enquanto raça a sua dignidade enquanto seres humanos e o mesmo tratamento dispensado a todos os brasileiros de outras raças.

Dar ao povo negro um tratamento desigual na medida em que são e estão desigualados, é muito pouco para uma sociedade que se beneficiou e cresceu a custa do sacrifício de milhares negros, que por quase quatro séculos trabalharam como escravos e não receberam qualquer indenização por esse trabalho. 


\section{Bibliografia}

ALLY, Raimundo Cerqueira. CONVENÇÃO 158: julho/setembro Revista do Direito do Trabalho. São Paulo: 1996

BANDEIRA, Lurdes Maria. Relações de Trabalho, Relações de Poder. UnB. Brasília. 1997.

BARROS, Alice Monteiro de. A Mulher e o Direito do Trabalho. São Paulo: LTr. 1995.

BOBBIO, Norberto. Igualdade e Liberdade. $3^{\mathrm{a}}$ ed. Rio de Janeiro: Ediouro, 1997.

CASTRO, Carlos Roberto de Siqueira. O Princípio da Isonomia e a Igualdade da Mulher no Direito Constitucional. Rio de Janeiro:Forense, 1983.

GOMES, Orlando. Curso de Direito do Trabalho.12a ed., Rio de Janeiro: 1991.

MELlo, Celso Antônio Bandeira de. O Conteúdo Jurídico do Princípio da Igualdade. São Paulo: Revista dos Tribunais, 1978.

MUNANGA, Kabengele. Políticas de Ação Afirmativa em Benefício da População Negra no Brasil: Um Ponto de Vista em Defesa de Cotas. www.espacoacademico.com.br. Disponível em 11/04/05.

ROCHA, Cármen Lúcia Antunes. O Princípio Constitucional da Igualdade. Belo Horizonte: LÊ S/A, 1990.

ROCHA, Cármen Lúcia Antunes. Ação Afirmativa: O Conteúdo Democrático do Princípio da Igualdade Jurídica. Revista Trimestral de Direito Público. $15 / 1996$.

RODRIGUEZ, Américo Plá, Princípios de Direito do Trabalho. Tradução: Wagner D. Giglio. São Paulo: LTr. 1978.

SEVERINO, Antônio Joaquim. Uma Proposta de Ação Afirmativa anti-racista no campo da educação. www.espacoacademico.com.br Disponível em $11 / 04 / 05$.

SILVA, José Afonso da. Curso de Direito Constitucional Positivo. 22a ed. São Paulo: Malheiros, 2003. 
SILVA, Maria Nilza da. A Mulher Negra. www.espacoacademico.com.br. Disponível em 11/04/05.

CONVEÇÃO $\mathrm{N}^{\circ} 100$ DA OIT RELATIVA À IGUALDADE DE REMUNERAÇÃO ENTRE A MÃO-DE-OBRA MASCULINA E A MÃODE-OBRA FEMININA EM TRABALHO DE VALOR IGUAL. www.gddc.pt/direitos-humanos/textos-internacionais-dh/ Disponível em $10 / 05 / 05$.

REVISTA DO DIREITO DO TRABALHO/ abril/junho. RT São Paulo: 1996.

CONSTITUIÇÃO DA REPUBLICA FEDERATIVA DO BRASIL. $3^{\mathrm{a}}$ ed. Rio de janeiro: Coleção Alerj. 1988.

PANO NACIONAL DE QUALIFICAÇÃO DO TRABALHADOR. $A$ Experiência dos Afro-brasileiros. Cadernos Temáticos. Brasília: Nirema-PUC. 1999/2000.

SOARES, Sergei Suarez Dillon. O perfil da discriminação no mercado de Trabalho. Brasília. 2000. 